\title{
PREDICTORS OF WATER QUALITY IN RURAL HEALTHCARE FACILITIES IN 14 LOW- AND MIDDLE-INCOME COUNTRIES
}

Amy Zhang Guo

A thesis submitted to the faculty at the University of North Carolina at Chapel Hill in partial fulfillment of the requirements for the degree of Master of Science in the Department of Environmental Sciences and Engineering in the Gillings School of Global Public Health.

\section{Chapel Hill}

2018

Approved by:

Jamie Bartram

Jill Stewart

Jackie MacDonald-Gibson 
(C) 2018

Amy Zhang Guo

ALL RIGHTS RESERVED 


\begin{abstract}
Amy Zhang Guo: Predictors of Water Quality in Rural Healthcare Facilities in 14 Low- and Middle-Income Countries

(Under the direction of Jamie Bartram)
\end{abstract}

Many healthcare facilities (HCFs) in rural areas of low- and middle-income countries (LMICs) lack safe, sufficient water supplies. We sought to understand which factors affect water quality in rural HCF in LMICs. In Ethiopia, Kenya, Rwanda, Uganda, Tanzania, Malawi, Mozambique, Zambia, Zimbabwe, Ghana, Mali, Niger, India, and Honduras, doctors and nurses were interviewed at 2,035 $\mathrm{HCFs}$ about their water source, staff training, and management practices. Water samples were also tested for E. coli contamination. We generated descriptive analyses and logistic regressions. Use of an improved water source $(\mathrm{OR} \approx 1.4)$, treatment of water $(\mathrm{OR}=1.26)$, management by a person with medical training $(\mathrm{OR} \approx 3.7)$, and presence of a protocol for operations and management $(\mathrm{OR}=1.29)$ were associated with safer water. These results suggest that in addition to addressing water source, storage, and treatment, stakeholders can also target organizational factors in order to improve water quality in HCFs. 


\section{ACKNOWLEDGEMENTS}

This research would not have been possible without the support of many people. I would like to thank my advisors and committee members, Jamie Bartram, Jill Stewart, and Jackie MacDonald-Gibson for their patient guidance and helpful comments on this work. I would also like to thank all my colleagues at the Water Institute for making this research possible, especially Ryan Cronk, who helped me troubleshoot problems during analysis and gave helpful feedback on my writing. I would also like to thank Cathy Zimmer, at the Howard W. Odum Institute, for her advice and guidance during the statistical data analysis.

This project was funded by World Vision (Federal Way, WA) and would not have been possible without the hard work of World Vision staff in each country, as well as the consulting

firms and enumerators who carried out the field work. Many thanks to all involved, including the doctors and nurses who contributed their precious time to this study.

Finally, I am extremely grateful to my friends and family for their continuous love, encouragement, and support. The tasty food, the sweet texts, and the cute dog photos brought me lots of joy. Thank you from the bottom of my heart. 


\section{TABLE OF CONTENTS}

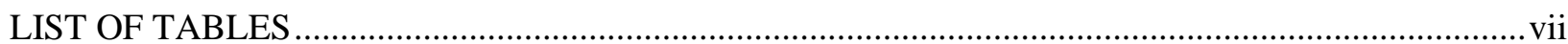

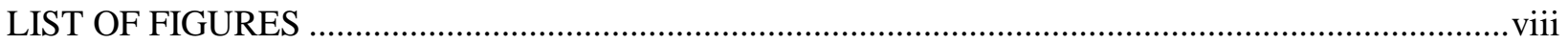

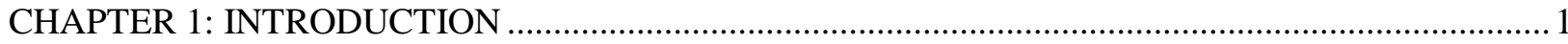

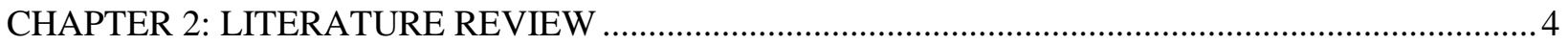

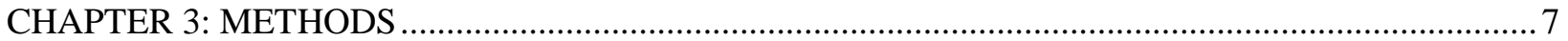

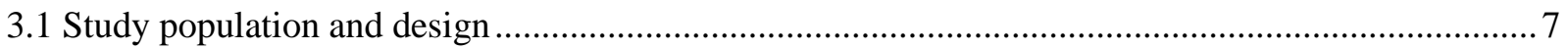



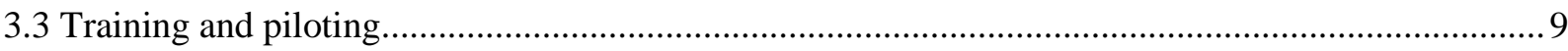

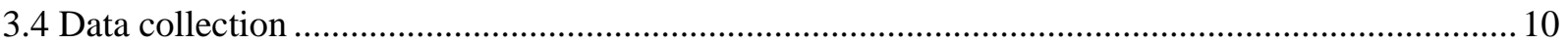

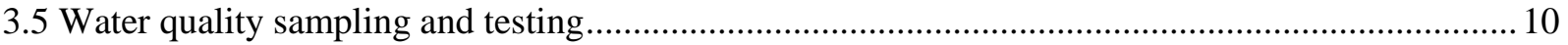



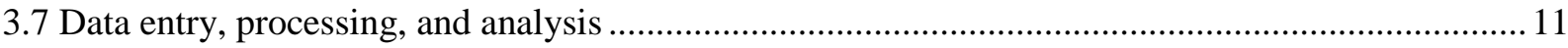

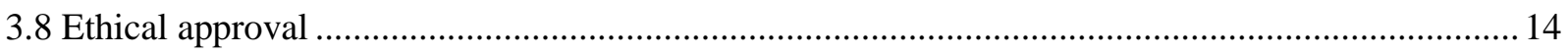



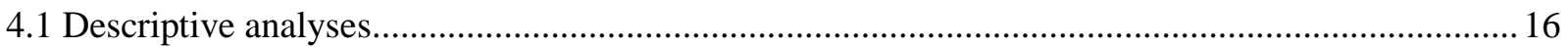

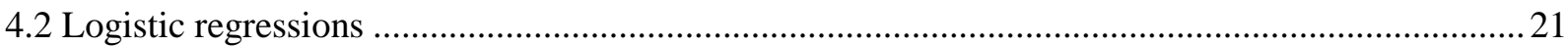

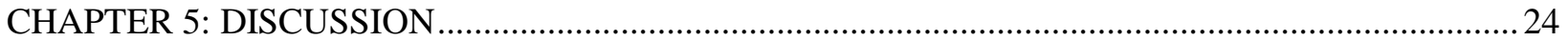

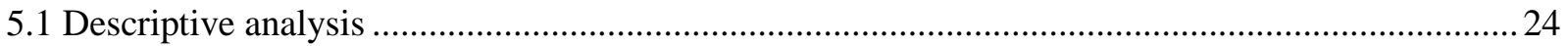




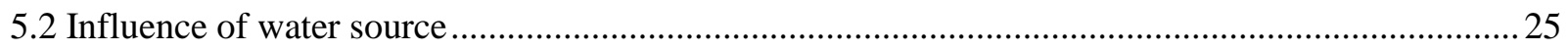

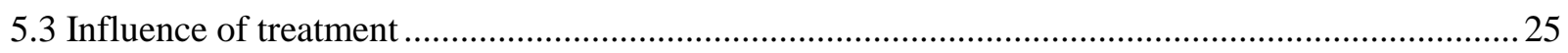

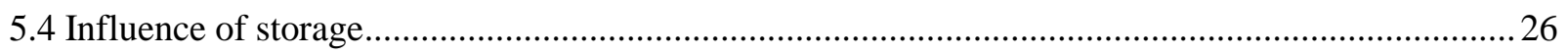

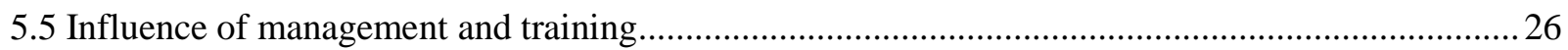





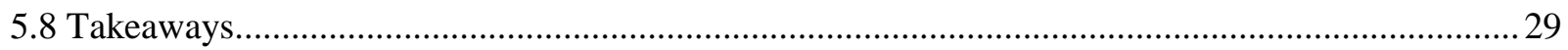

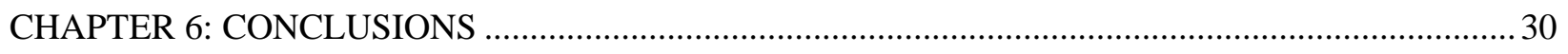

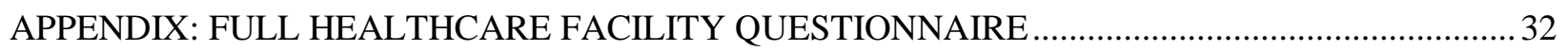

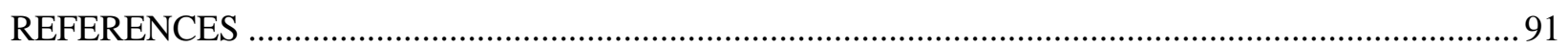




\section{LIST OF TABLES}

Table 1. Variables selected for testing in logistic regressions. ............................................ 12

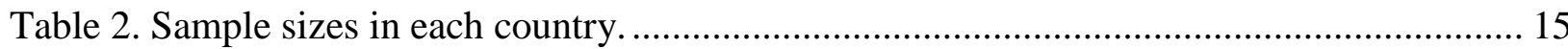

Table 3. Characteristics of surveyed healthcare facilities and medical training of facility managers in each country.

Table 4. Proportion of healthcare facilities with an improved main water source and safe storage and treatment practices.

Table 5. Proportion of healthcare facilities where IPC and WaSH-related training or management programs were reported.

Table 6. Proportion of healthcare facilities where water was in conformity with drinking-water quality guidelines (as defined by WHO) at the time of survey, by country

Table 7. Factors associated with conformity with drinking-water quality guidelines (as defined by WHO in univariable logistic models, by country.

Table 8. Factors associated with statistically significant changes in water quality risk level (as defined by WHO), across all 14 aggregated countries in a multivariable logistic model. 


\section{LIST OF FIGURES}

Figure 1. GPS location of healthcare facilities visited in each country ................................ 8 


\section{CHAPTER 1: INTRODUCTION}

Safe and sufficient water services are vital for protecting and maintaining health. Consumption of contaminated water or having insufficient water for personal hygiene is linked to diseases such as cholera, typhoid fever, helminth infections, and trachoma (Prüss-Ustün et al., 2014). In 2015, the need for basic water services was recognized in Goal 6 of the United Nations' Sustainable Development Goals (SDGs), where target 6.1 calls for universal access to "safe and affordable drinking-water for all" and target 6.3 calls for improvements in water quality by 2030 (UN, 2017). However, achieving and maintaining adequate water service can be difficult in low- and middle-income countries (LMICs), even more so in rural areas of LMICs (R. E. S. Bain, Wright, Christenson, \& Bartram, 2014).

The WHO/UNICEF Joint Monitoring Programme has also specified that "universal access" to drinking-water includes settings such as schools, workplaces, and healthcare facilities (HCFs) (UN Special Rapporteur on the Human Right to Safe Drinking Water and Sanitation, 2012). Adequate quantities of safe water are particularly important within HCFs in order to maintain a clean environment and prevent the spread of healthcare-associated infections such as urinary tract, surgical-site, lower respiratory tract, and bloodstream infections (Adams et al., 2008; Mathai, Allegranzi, Kilpatrick, \& Pittet, 2010). In HCFs, water is used for not only drinking by patients and staff, but also for hand hygiene, bathing patients, washing linens, sterilizing medical equipment, and cleaning surfaces in the facility (Adams et al., 2008). When an HCF's water supply is of insufficient quantity or unsafe quality, its ability to provide safe 
medical services is compromised. In a study of healthcare workers in ten rural Indonesian clinics, observed hand hygiene compliance was only $20 \%$, in part due to water scarcity: one worker commented, "We don't even have water to drink or cook; how could you expect us to bathe regularly, let alone wash our hands?” (Marjadi \& McLaws, 2010). An inadequate water supply can also lead to negative perceptions of the HCF by patients (Bhattacharyya, Issac, Rajbangshi, Srivastava, \& Avan, 2015; Karkee, Lee, \& Pokharel, 2014; Steinmann et al., 2015), as well as decreased morale and motivation of healthcare workers at the facility (Alhassan et al., 2013; Melberg, Diallo, Tylleskär, \& Moland, 2016).

An assessment of monitoring data on water supplies in HCFs from 78 LMICs estimated that $50 \%$ of HCFs do not have a piped water source on-premises (Cronk \& Bartram, 2018). Data on microbial water quality in LMIC HCFs are sparse: most published studies are limited to 20 or 30 water samples in ten or fewer facilities. However, one cross-sectional study found that $15.3 \%$ of water samples from HCFs in rural Uganda $(n=144)$ and $29.6 \%$ of water samples from rural Mozambique (n=172) were contaminated with E. coli (Guo, Bowling, Bartram, \& Kayser, 2017). No known studies model the relationships between water quality in rural HCF in LMIC and other factors such as HCF management characteristics, characteristics of water source, water storage and treatment practices. Such studies would be useful in identifying interventions and management solutions to improve the situation. The relationships between environmental outcomes (such as water quality) and explanatory factors are complex, non-linear, and require analytical approaches that can capture these complexities. We conducted surveys and water quality sampling at HCFs which provided outpatient care only within 14 LMICs (Ethiopia, Kenya, Rwanda, Uganda, Tanzania, Ghana, Mali, Niger, Malawi, Mozambique, Zambia, 
Zimbabwe, India, Honduras). Through descriptive statistics and logistic regressions, we sought to understand the following:

1. What is the current status of water service and water quality within rural HCFs in LMIC?

2. What factors (general HCF characteristics, training, water source characteristics, etc.) have the greatest impact on water quality within rural HCFs in LMIC?

3. Which of these factors can be modified to improve water quality within rural HCFs? 


\section{CHAPTER 2: LITERATURE REVIEW}

Factors that impact water quality have been studied for other settings. A review of key predictors of water quality has been compiled here.

Location and time. Water quality is related to geographical location. This is most obvious with geogenic chemical contaminants of water, such as arsenic and fluoride (WHO, 2017), but location is also an important factor in understanding microbiological water quality. Water sources within several meters or downhill from sources of contamination such as latrines, animals, and fertilizers are at greater risk of contamination. Microbial contamination of water also naturally fluctuates over time due to factors such as rainfall, temperature, exposure to sunlight, etc. which affect the growth and survival of microbes in water. Drinking water sources are more likely to be fecally contaminated during the wet season than in the dry season (Kostyla, Bain, Cronk, \& Bartram, 2015).

Source characteristics. The WHO/UNICEF Joint Monitoring Program categorizes water sources as "improved" or "unimproved" based on their construction (JMP, 2017). Improved sources of water - piped water into a dwelling, piped water into the yard, public taps, boreholes, protected dug wells, protected springs, rainwater collection, and bottled water - are less likely to be fecally contaminated than unimproved sources. However, improved status is not a guarantee of safety; water from improved sources can be contaminated with fecal bacteria, and protected dug wells are frequently contaminated (R. Bain et al., 2014). Intermittent water supplies are also 
more likely to be fecally contaminated, with $31.7 \%$ of samples from an intermittent tap supply testing positive for E. coli as opposed to $0.7 \%$ of samples from a continuous tap supply in one study (Kumpel \& Nelson, 2013). Damaged parts at the water source can also introduce contamination: this might correspond to items on the WHO sanitary inspection for water points, such as a cracked drainage channel, loose handpump, or broken platform. As with source type, a "low risk" score on the sanitary inspection corresponds with greater likelihood of safe water, but does not guarantee safety (Luby et al., 2008; Oliver, 2015).

Storage and treatment. While distance to source is usually discussed because of its implications for water quantity, shorter distances to water source have been linked to better water quality in Ethiopia (K. Shields et al., 2015). Without treatment, water tends to become more contaminated from source to point-of-use; this deterioration tends to be worse in households where water containers are not covered, and the water inside can be directly touched by hands (Wright, Gundry, \& Conroy, 2004). Fecal contamination can be mitigated by treatment using methods such as chlorination and filtration, but each method for treating water will have differential effectiveness against different types of microorganisms (for example protozoa and viruses) (WHO, 2017).

Sanitation and waste management. Sanitation facilities in disrepair (for example, leaking, flooding, or cracked) can contaminate both surface water and groundwater, though the extent of contamination is dependent on soil type and water table level in the area (Escamilla, Knappett, Yunus, Streatfield, \& Emch, 2013; Graham, 2014). Groundwater is more likely to be contaminated by latrines in rocky soils and areas with shallow water tables. Sanitation facilities are also more likely to contaminate water when uphill or a short distance from water source: while a lateral separation of $15 \mathrm{~m}$ is "traditionally" recommended, a systematic review found that 
bacteria from pit latrines can travel over $20 \mathrm{~m}$ in some soils, and that viruses can travel up to 50 $\mathrm{m}$ from the latrine, contaminating groundwater (Graham, 2014).

Management and finance. The presence of a water or WaSH committee responsible for management of a water point is associated with increased functionality (Fechter, 2017). Specific management actions by management committees, such as collection of a tariff, are also associated with increased source functionality (Fisher et al., 2015).

In this study, we set out to describe the status of these factors - location, source characteristics, water storage and treatment, sanitation, and management and finance - as well as determine the influence of these factors on microbial water quality in healthcare facilities within rural areas of low- and middle-income countries. This was done using the data from a large multi-country study, which is described in more detail in Chapter 3 (Methods) below. 


\section{CHAPTER 3: METHODS}

\subsection{Study population and design}

This study examined healthcare facilities (HCFs) in rural areas of 14 countries: Ethiopia, Kenya, Rwanda, Uganda, Tanzania, Ghana, Mali, Niger, Zambia, Malawi, Mozambique, Zimbabwe, India, and Honduras. This study was part of a larger evaluation of WaSH in World Vision (an international NGO) programming areas and comparison areas. This larger evaluation also examined WaSH in households, communities, and schools. The HCF sample frame was nested within the household survey design, which was a cluster-randomized design to reduce study costs and simplify travel logistics for data collectors. In the household design, rural enumeration areas were identified across each country and classified as areas where World Vision has active WaSH programs or areas where World Vision does not work; within each stratum, 56 primary sampling units were identified where households would be mapped and surveyed.

After the geographic areas for household surveys were selected, a full list of healthcare facilities was compiled (usually from a master health facility list from each country) within the administrative districts in which the household clusters were identified. Facilities where inpatient care was provided (such as hospitals) were excluded from this list, as the water needs for $\mathrm{HCF}$ providing inpatient care and HCF providing outpatient care are likely to be different. Simple random samples were taken from this list, so that in each country, $100 \mathrm{HCFs}$ were selected for surveys in World Vision programming areas and $100 \mathrm{HCFs}$ were selected from comparison areas 
where World Vision did not have programming. In some countries where there were not enough HCFs in the selected districts to meet this goal sample size, HCFs were included from nearby areas (for example, in Ghana, HCFs within a 10-km buffer of the selected districts were included in the sample frame). The locations of surveyed healthcare facilities are displayed in Figure 1.



Figure 1. GPS location of healthcare facilities visited in each country. This map shows the distribution of surveyed HCF in 13 countries. Results from this study are generalizable to the indicated subnational districts within each country. GPS data were not collected in India by requirement of local IRB.

\subsection{Survey instrument}

The survey instrument for this study was adapted from a baseline evaluation of WaSH for World Vision (Kayser et al. 2015), and included questions on healthcare facility characteristics; water (source type, distance to source, availability, water storage, treatment), sanitation (type, 
functionality, condition, and use); hygiene (hand hygiene, sharps and infectious waste segregation and treatment and disposal); and administration and training (policies, budget, trainings on $\mathrm{WaSH}$ and infection prevention and control). These surveys were translated into local languages for each country and verified by research consultants or World Vision staff in each country.

Some of the questions from the survey were asked to the interviewee, while others were observed and recorded by the enumerator. Survey responses were recorded using the mobile survey tool mWater (New York, NY, USA).

\subsection{Training and piloting}

Research consulting firms were hired to conduct the surveys in each country. While the hiring process for enumerators was slightly different in each country, most firms sought enumerators with the equivalent of a high-school education, with preference given to women and to candidates with past surveying experience, knowledge of $\mathrm{WaSH}$, and/or expertise using mobile phones.

Staff from the Water Institute at the University of North Carolina at Chapel Hill conducted five regional training workshops (East Africa, Southern Africa, West Africa, Honduras, and India) in-person in order to familiarize consultants and enumerators with the survey, surveying techniques, use of the mWater mobile platform, protocol for taking water samples, and quality checks for data. One additional training workshop was conducted via Skype for the consultant team in Honduras. Consultants in each country also held a 'refresher' training workshop for their enumerators just before data collection commenced.

After each regional training workshop, Water Institute staff remained with World Vision staff, consultants, and enumerators for a three-day piloting period. During this, enumerators 
visited several villages and practiced all procedures for entering communities and completing surveys, such as mapping of healthcare facilities and water points in each area, process for taking and reading water quality results, practice filling out and submitting surveys using the mWater platform, and discussion of the verification and quality assurance and quality control processes that should be performed on enumerators' surveys.

\subsection{Data collection}

Data were collected over two to three months in each country, with the earliest country finishing data collection in July 2017 and the last country finishing data collection in December 2017. During the data collection period, teams of enumerators went to each selected facility and attempted to interview the head doctor. If the head doctor was unavailable, they attempted to interview the head nurse. If the head nurse was unavailable, a nurse who had worked at the health center for more than two years was interviewed. The respondent was allowed to decline to respond to any question, and to stop the survey at any time (see Section 3.8, Ethical approval).

\subsection{Water quality sampling and testing}

In all visited HCFs, interviewees were asked if they could serve water in the manner someone would usually take it for drinking. A $100-\mathrm{mL}$ sample of that water was taken for a Compartment Bag Test (CBT) (Aquagenx, Chapel Hill, NC, USA), a low-cost field test for fecal contamination using Escherichia coli as indicator organism. Guidelines for taking a water sample without contamination were followed (Madsen and Guo 2014). Blank samples were collected at $10 \%$ of HCFs and duplicate water samples were collected at another $10 \%$ of HCFs as a check on the quality of data collected on water contamination.

To test for $E$. coli, water samples were processed immediately after each survey: these were incubated in a CBT for 48 hours at ambient temperature between 25 and 30 degrees 
Celsius, 24 hours at ambient temperature above 30 degrees Celsius. In cases where the ambient temperature was not between 25 and 30 degrees Celsius, water samples were stored in a cooler with ice until the end of the day in the field, then were placed in a 35 to 37 degree incubator for 24 hours. These samples were then categorized by risk level based on E. coli per $100 \mathrm{~mL}$ sample, either "safe" (<1 MPN E. coli per $100 \mathrm{~mL}$ ) or "unsafe" (1 or more MPN per $100 \mathrm{~mL})$.

\subsection{Quality assurance and control}

Quality checks were in place for multiple stages of data collection. These were built-in checks from the mWater platform to prevent skipped questions (so that enumerators could not continue with the survey without answering questions or indicating that the respondent did not want to answer a question) and a list of checks for supervisors to complete each week while reviewing new data (common-sense checks on number of surveys completed, duration of surveys, number of water samples collected, location of GPS points in country, verification of certain responses based on photos).

During data collection, consultants and their enumerator teams had access to manuals for enumerators and supervisors; enumerators were also able to ask for support or clarification from their supervisors or other enumerators via text message or WhatsApp. The research team at UNC also provided support via Skype, email, and WhatsApp.

At the conclusion of the data collection period for each country, data were reviewed and consultants were called via Skype to clarify any remaining items (for example, explanation for why sample sizes were lower than expected).

\subsection{Data entry, processing, and analysis}

Datasets were exported from mWater into Stata/SE 14.2 (College Station, TX, USA) for cleaning and analysis. Analysis was done in Stata using tab, proportion, tabstat, pwcorr, logistic, 
and melogit commands. This included individual logistic regression models within each country, as well as a mixed effects logistic regression model using the aggregated data from all 14 countries.

Variables from the survey were selected a priori for testing based on evidence of factors that influence water quality or plausible relationship (Table 1).

Table 1. Variables selected for testing in logistic regressions.

\begin{tabular}{|c|c|}
\hline Category & Variables \\
\hline $\begin{array}{l}\text { HCF } \\
\text { characteristics }\end{array}$ & $\begin{array}{l}\text { - Healthcare facility type } \\
\text { - } \text { Average number of patients served each day } \\
\text { - } \quad \text { Highest level of medical training for facility manager } \\
\text { - }\end{array}$ \\
\hline $\begin{array}{l}\text { Water source and } \\
\text { handling }\end{array}$ & $\begin{array}{ll}\text { - } & \text { Main water source type } \\
\text { - } & \text { Distance to water source } \\
\text { - } & \text { Storage and method of extracting water from container } \\
\text { - } & \text { Treatment of water } \\
\text { - } & \text { Continuity of water service } \\
\text { - } & \text { Number of hours of water service each week }\end{array}$ \\
\hline $\begin{array}{l}\text { Sanitation facility } \\
\text { characteristics }\end{array}$ & $\begin{array}{l}\text { - Type of sanitation facilities used by people at the healthcare facility } \\
\text { - Number of sanitation facilities used by people at the healthcare facility } \\
\text { - Open defecation at facility } \\
\text { - Sanitation service level (as defined by JMP) }\end{array}$ \\
\hline $\begin{array}{l}\text { Institutional } \\
\text { organization on } \\
\text { WaSH (water, } \\
\text { sanitation, and } \\
\text { hygiene) and IPC } \\
\text { (infection } \\
\text { prevention and } \\
\text { control) }\end{array}$ & $\begin{array}{l}\text { - Presence of an infection prevention and control policy or document } \\
\text { - Sufficient budget for the facility's WaSH/IPC infrastructure, services, and } \\
\text { personnel } \\
\text { - Presence of a protocol for operations and maintenance of the facility, } \\
\text { including procurement of IPC and WaSH supplies } \\
\text { - Presence of a dedicated IPC or WaSH focal person } \\
\text { - Presence of an IPC/WaSH/hygiene committee which employees at the } \\
\text { facility belong to } \\
\text { - Presence of a community-composed oversight committee } \\
\text { - } \text { Attendance of doctors, nurses, environmental health officers, and } \\
\text { janitors/maintenance workers at IPC trainings }\end{array}$ \\
\hline
\end{tabular}

Categorical responses were cleaned so that responses of "don't know," "decline to state," "not applicable," etc. were counted as missing data. Some responses were categorized (for example, main water source into improved and unimproved based on guidance from the JMP (JMP, 2016); method for extracting water from a storage container sorted into safe if by pouring, 
dispensed from a tap or spigot, or scooped with a ladle, or unsafe scooping with hands or a cup). New variables were also coded based on composites of other responses - for example, water service levels were calculated based on main water source, availability of water at time of survey, and distance to water source, where HCFs with an improved water source on-premises with water available during the survey used a basic water service, HCFs with an improved source of water off-premises or not available during the survey used a limited water service, and HCFs with an unimproved or no source of water had no water service (JMP, 2016). Water quality was recoded as a binary outcome based on the MPN of $E$. coli reported $(<1 \mathrm{MPN}$ per $100 \mathrm{~mL}=$ “safe," 1 or more MPN per $100 \mathrm{~mL}=$ "unsafe"). For continuous variables, out-of-range values were also removed (for example, one response in Niger stated that the HCF served an average of 96,239,883 patients each day).

Univariable logistic regressions were performed to identify predictors of water quality within each country. All variables selected for testing were run as univariate logistic models; we identified variables that had a statistically significant Wald chi-squared value (associated $\mathrm{p}<$ $0.05)$ and report these.

For the multivariable mixed-effects logistic model, we clustered results based on country and again ran univariate mixed-effects logistic models in order to identify variables with statistically significant relationships with the outcome variable (safe water). All variables identified as significantly associated with the outcome were included in the multivariable model. These variables were also tested for collinearity using Pearson's correlation coefficient and the variance inflation factor. 


\subsection{Ethical approval}

This study was approved by the UNC-Chapel Hill Institutional Review Board (IRB \#170663). Free and informed consent was obtained from all participants in their own language before beginning the survey.

Ethical approval was also obtained by agencies within each of the countries. These were the National Regional Government of Oromia Planning and Economic Development Commission in Ethiopia, the Ministry of Water and Irrigation in Kenya, the Ministry of Infrastructure in Rwanda, the Makarere University School of Biomedical Sciences ethics committee in Uganda, the National Institute for Medical Research in Tanzania, the Ministry of Water Resources in Ghana, the University of Bamako Medical School in Mali, the Ministry of Water Resources in Niger, the Director of Irrigation and Water Development in Malawi, the National Institute of Statistics in Mozambique, the Ministry of Local Government and Housing in Zambia, the Medical Research Council in Zimbabwe, the SRM University School of Public Health in India, and the Secretary of Energy and Natural Resources in Honduras. 


\section{CHAPTER 4: RESULTS}

A total of 2,035 healthcare facilities (HCFs) were successfully contacted for surveys, with a sample size target of 2,800 (200 surveys per country). Water samples were taken at all HCFs where water was available on the day of the survey, or 1,679 of the HCFs (Table 2).

Table 2. Sample sizes in each country.

\begin{tabular}{|l|l|c|c|}
\hline Region & Country & $\begin{array}{l}\text { Number of } \\
\text { completed } \\
\text { surveys }\end{array}$ & $\begin{array}{l}\text { Number of } \\
\text { water samples }\end{array}$ \\
\hline Eastern Africa & Ethiopia & 187 & 96 \\
\cline { 2 - 4 } & Kenya & 165 & 156 \\
\cline { 2 - 4 } & Rwanda & 87 & 80 \\
\cline { 2 - 4 } & Uganda & 77 & 68 \\
\cline { 2 - 4 } & Tanzania & 149 & 132 \\
\hline \multirow{5}{*}{ Southern Africa } & Zambia & 163 & 150 \\
\cline { 2 - 4 } & Malawi & 137 & 117 \\
\cline { 2 - 4 } & Mozambique & 138 & 125 \\
\cline { 2 - 4 } & Zimbabwe & 119 & 82 \\
\hline Western Africa & Ghana & 176 & 165 \\
\cline { 2 - 4 } & Mali & 118 & 111 \\
\cline { 2 - 4 } & Niger & 173 & 198 \\
\hline Southern Asia & India & 209 & 1679 \\
\hline Southern Americas & Honduras & 137 & \\
\hline & TOTAL & 2035 & \\
\cline { 2 - 4 } & & & \multicolumn{2}{|c|}{} \\
\hline \multirow{3}{*}{} & & & 118 \\
\hline
\end{tabular}


4.1 Descriptive analyses

Across all 14 countries, the most commonly surveyed type of HCF was the health center. However, health posts were the most common type of HCF surveyed in Ethiopia and Tanzania; the community/block health center was most common in Rwanda and Mali; the primary health center was most common in Zimbabwe; and the sub-center was most common in India. The most frequently indicated "Other" healthcare facilities were dispensaries (Kenya, Tanzania), Community Health-Based Planning and Services or CHPS compounds (Ghana), Case de Santé or 'health huts' (Niger), and Centros de Salud Rural or 'rural health centers' (Honduras).

Across all countries, HCFs were most commonly managed by nurses. The most frequently indicated "Other" levels of medical training for HCF managers were clinical/medical assistants (Malawi), medical technicians (Mozambique, Mali), physician assistants (Ghana), health officers (Mozambique, Niger), auxiliary nurse midwives or ANMs (India), accredited social health activist or ASHA workers (India), and nursing assistants (Honduras) (Table 3). 
Table 3. Characteristics of surveyed healthcare facilities and medical training of facility managers in each country.

\begin{tabular}{|c|c|c|c|c|c|c|c|c|c|c|c|c|c|c|}
\hline & \multicolumn{5}{|c|}{ Eastern Africa } & \multicolumn{4}{|c|}{ Southern Africa } & \multicolumn{3}{|c|}{ West Africa } & \multirow{2}{*}{$\begin{array}{l}\begin{array}{l}\text { Southern } \\
\text { Asia }\end{array} \\
\text { India } \\
(\%)\end{array}$} & \multirow{2}{*}{$\begin{array}{l}\begin{array}{l}\text { Southern } \\
\text { Americas }\end{array} \\
\text { Honduras } \\
(\%)\end{array}$} \\
\hline & $\begin{array}{l}\text { Ethiopia } \\
(\%)\end{array}$ & $\begin{array}{l}\text { Kenya } \\
(\%)\end{array}$ & $\begin{array}{l}\begin{array}{l}\text { Rwanda } \\
(\%)\end{array} \\
\end{array}$ & $\begin{array}{l}\text { Uganda } \\
(\%)\end{array}$ & $\begin{array}{l}\text { Tanzania } \\
(\%)\end{array}$ & $\begin{array}{l}\text { Zambia } \\
(\%)\end{array}$ & $\begin{array}{l}\text { Malawi } \\
(\%)\end{array}$ & $\begin{array}{l}\text { Mozambique } \\
(\%)\end{array}$ & $\begin{array}{l}\text { Zimbabwe } \\
(\%)\end{array}$ & $\begin{array}{l}\begin{array}{l}\text { Ghana } \\
(\%)\end{array} \\
\end{array}$ & $\begin{array}{l}\text { Mali } \\
(\%)\end{array}$ & $\begin{array}{l}\text { Niger } \\
(\%)\end{array}$ & & \\
\hline $\begin{array}{l}\text { Type of HCF } \\
\text { Health post } \\
\text { Health center } \\
\text { Private clinic } \\
\text { Sub center } \\
\text { Primary health center } \\
\text { Community/block health } \\
\text { center } \\
\text { Other }\end{array}$ & $\begin{array}{l}66 \\
30 \\
1 \\
1 \\
1 \\
<1 \\
0\end{array}$ & $\begin{array}{l}5 \\
48 \\
3 \\
17 \\
2 \\
6 \\
19\end{array}$ & $\begin{array}{l}12 \\
0 \\
0 \\
0 \\
1 \\
86 \\
0\end{array}$ & $\begin{array}{l}1 \\
94 \\
5 \\
0 \\
0 \\
0 \\
0\end{array}$ & $\begin{array}{l}57 \\
17 \\
1 \\
0 \\
7 \\
9 \\
9\end{array}$ & $\begin{array}{l}15 \\
75 \\
2 \\
<1 \\
1 \\
7 \\
0\end{array}$ & $\begin{array}{l}2 \\
87 \\
6 \\
<1 \\
2 \\
<1 \\
1\end{array}$ & $\begin{array}{l}1 \\
96 \\
0 \\
2 \\
0 \\
0 \\
0\end{array}$ & $\begin{array}{l}<1 \\
18 \\
5 \\
2 \\
71 \\
3 \\
0\end{array}$ & $\begin{array}{l}1 \\
34 \\
6 \\
2 \\
6 \\
16 \\
27\end{array}$ & $\begin{array}{l}0 \\
35 \\
0 \\
0 \\
4 \\
55 \\
6\end{array}$ & $\begin{array}{l}16 \\
26 \\
23 \\
5 \\
2 \\
15 \\
15\end{array}$ & $\begin{array}{l}3 \\
18 \\
0 \\
48 \\
27 \\
3 \\
<1\end{array}$ & $\begin{array}{l}<1 \\
81 \\
<1 \\
<1 \\
2 \\
<1 \\
14\end{array}$ \\
\hline $\begin{array}{l}\text { Level of medical training for } \\
\text { HCF manager } \\
\text { Doctor } \\
\text { Nurse } \\
\text { Community health } \\
\text { worker/health extension worker } \\
\text { Midwife } \\
\text { Other } \\
\text { None }\end{array}$ & $\begin{array}{l}1 \\
55 \\
28 \\
\\
0 \\
10 \\
5\end{array}$ & $\begin{array}{l}10 \\
71 \\
0 \\
0 \\
18 \\
<1\end{array}$ & $\begin{array}{l}0 \\
98 \\
0 \\
\\
0 \\
2 \\
0\end{array}$ & $\begin{array}{l}16 \\
53 \\
0 \\
\\
5 \\
26 \\
0\end{array}$ & $\begin{array}{l}50 \\
36 \\
0 \\
0 \\
14 \\
<1\end{array}$ & $\begin{array}{l}2 \\
77 \\
6 \\
4 \\
10 \\
0\end{array}$ & $\begin{array}{l}10 \\
19 \\
0 \\
0 \\
71 \\
<1\end{array}$ & $\begin{array}{l}10 \\
61 \\
0 \\
0 \\
29 \\
<1\end{array}$ & $\begin{array}{l}2 \\
93 \\
0 \\
\\
3 \\
2 \\
0\end{array}$ & $\begin{array}{l}7 \\
61 \\
2 \\
13 \\
17 \\
0\end{array}$ & $\begin{array}{l}52 \\
24 \\
0 \\
0 \\
25 \\
0\end{array}$ & $\begin{array}{l}2 \\
59 \\
28 \\
\\
0 \\
11 \\
0\end{array}$ & $\begin{array}{l}24 \\
50 \\
<1 \\
\\
0 \\
21 \\
5\end{array}$ & $\begin{array}{l}40 \\
54 \\
0 \\
\\
0 \\
0 \\
6\end{array}$ \\
\hline $\begin{array}{l}\text { Median number of patients } \\
\text { served each day }\end{array}$ & 10 & 50 & 75 & 50 & 30 & 45 & 150 & 80 & 45 & 20 & 16.5 & 17 & 11 & 20 \\
\hline
\end{tabular}

At the 2,035 HCFs surveyed, $86 \%$ of interviewees reported that the main water source used by people at the facility was an improved water source, such as a piped connection or a borehole with handpump. At $87 \%$ of HCFs, water was available from the main water source at the time of the survey. At $36 \%$ of HCFs, interviewees reported that their HCF's main water source was off-premises. However, in Ethiopia and Niger, the water source was more likely to be off-premises than on-premises. Overall, $52 \%$ of the surveyed HCFs used a basic water service, 34\% used a limited water service, and 14\% had no service as defined by the WHO/UNICEF Joint Monitoring Programme (Table 4). 
For healthcare facilities where water was stored in a container $(n=1,292), 96 \%$ reported that they used a container covered with a lid. Treatment of water was uncommon in some countries (with water treated in $10 \%$ of HCFs in Zimbabwe), but was more widespread in others (with water treated in $80 \%$ of in HCFs in Rwanda) (Table 4).

Table 4. Proportion of healthcare facilities with an improved main water source and safe storage and treatment practices. (Point estimates are shown \pm standard error.)

\begin{tabular}{|c|c|c|c|c|c|c|c|c|c|c|c|c|c|c|}
\hline & \multicolumn{5}{|c|}{ Eastern Africa } & \multicolumn{4}{|c|}{ Southern Africa } & \multicolumn{3}{|c|}{ West Africa } & \multirow{2}{*}{$\begin{array}{l}\begin{array}{l}\text { Southern } \\
\text { Asia }\end{array} \\
\text { India } \\
(\%)\end{array}$} & \multirow{2}{*}{$\begin{array}{l}\begin{array}{l}\text { Southern } \\
\text { Americas }\end{array} \\
\begin{array}{l}\text { Honduras } \\
(\%)\end{array}\end{array}$} \\
\hline & $\begin{array}{l}\text { Ethiopia } \\
\text { (\%) }\end{array}$ & $\begin{array}{l}\begin{array}{l}\text { Kenya } \\
(\%)\end{array}\end{array}$ & $\begin{array}{l}\text { Rwanda } \\
(\%)\end{array}$ & $\begin{array}{l}\text { Uganda } \\
(\%)\end{array}$ & $\begin{array}{l}\text { Tanzania } \\
(\%)\end{array}$ & $\begin{array}{l}\text { Zambia } \\
(\%)\end{array}$ & $\begin{array}{l}\text { Malawi } \\
(\%)\end{array}$ & $\begin{array}{l}\text { Mozambique } \\
(\%)\end{array}$ & $\begin{array}{l}\text { Zimbabwe } \\
(\%)\end{array}$ & $\begin{array}{l}\text { Ghana } \\
(\%)\end{array}$ & $\begin{array}{l}\text { Mali } \\
(\%)\end{array}$ & $\begin{array}{l}\text { Niger } \\
(\%)\end{array}$ & & \\
\hline $\begin{array}{l}\text { The main water } \\
\text { source used by } \\
\text { people at the } \\
\text { facility is } \\
\text { improved. }\end{array}$ & $84 \pm 3$ & $94 \pm 2$ & $96 \pm 2$ & $94 \pm 2$ & $73 \pm 4$ & $97 \pm 1$ & 100 & $92 \pm 2$ & $97 \pm 1$ & $87 \pm 3$ & $99 \pm 0.9$ & $70 \pm 4$ & $94 \pm 2$ & $89 \pm 3$ \\
\hline $\begin{array}{l}\text { The main water } \\
\text { source is available } \\
\text { on premises. }\end{array}$ & $24 \pm 3$ & $68 \pm 4$ & $84 \pm 4$ & $69 \pm 4$ & $54 \pm 4$ & $78 \pm 3$ & $84 \pm 3$ & $60 \pm 4$ & $69 \pm 4$ & $51 \pm 4$ & $93 \pm 2$ & $35 \pm 4$ & $54 \pm 3$ & $63 \pm 4$ \\
\hline $\begin{array}{l}\text { Water was } \\
\text { available from the } \\
\text { main water source } \\
\text { at the time of } \\
\text { survey. }\end{array}$ & $61 \pm 4$ & $94 \pm 2$ & $94 \pm 3$ & $94 \pm 2$ & $82 \pm 3$ & $78 \pm 3$ & $93 \pm 2$ & $71 \pm 4$ & $89 \pm 3$ & $92 \pm 6$ & $94 \pm 2$ & $68 \pm 4$ & $86 \pm 2$ & $66 \pm 4$ \\
\hline $\begin{array}{l}\text { (Of facilities who } \\
\text { store water) } \\
\text { Water is stored in } \\
\text { a safely covered } \\
\text { container. }\end{array}$ & $86 \pm 4$ & $98 \pm 1$ & 100 & $98 \pm 1$ & $97 \pm 1$ & 100 & $99 \pm 1$ & $96 \pm 2$ & $95 \pm 3$ & $98 \pm 1$ & $97 \pm 2$ & $96 \pm 2$ & $95 \pm 2$ & $89 \pm 4$ \\
\hline $\begin{array}{l}\text { People at the } \\
\text { facility use some } \\
\text { method to treat } \\
\text { their water before } \\
\text { drinking it. }\end{array}$ & $30 \pm 4$ & $57 \pm 4$ & $80 \pm 4$ & $57 \pm 4$ & $48 \pm 4$ & $37 \pm 3$ & $21 \pm 4$ & $39 \pm 4$ & $10 \pm 3$ & $6 \pm 2$ & $26 \pm 4$ & $26 \pm 3$ & $31 \pm 3$ & $46 \pm 4$ \\
\hline $\begin{array}{l}\text { The main water } \\
\text { source has } \\
\text { continuous } \\
\text { service (water } \\
\text { available from the } \\
\text { source } 24 \text { hours a } \\
\text { day). }\end{array}$ & $49 \pm 4$ & $73 \pm 4$ & $85 \pm 4$ & $73 \pm 4$ & $78 \pm 3$ & $80 \pm 3$ & $89 \pm 3$ & $89 \pm 3$ & $88 \pm 3$ & $92 \pm 2$ & $89 \pm 3$ & $73 \pm 3$ & $79 \pm 3$ & $61 \pm 4$ \\
\hline
\end{tabular}


Characteristics of management and training programs within HCFs on water, sanitation, and hygiene (WaSH) and infection prevention and control (IPC) varied by country (Table 5).

The existence of an IPC policy in HCFs ranged from 27\% in Niger to 96\% in Zimbabwe. Similar ranges existed for existence of operation and management protocols, designation of an IPC/WaSH focal person, and existence of WaSH and oversight committees. Communitycomposed oversight committees (groups of community members who can relay community health concerns and general feedback on quality of care to staff at the HCF) were more common than HCF WaSH committees.

At least half of the facilities in each country had held at least one IPC training in the past year (with the exceptions of healthcare facilities in Malawi and Niger); these had usually been attended by nurses rather than doctors or other workers in the facility.

About a fifth of facilities in most countries had a sufficient budget for IPC/WaSH supplies. 
Table 5. Proportion of healthcare facilities where IPC and WaSH-related training or management programs were reported. (Point estimates are shown \pm standard error.)

\begin{tabular}{|c|c|c|c|c|c|c|c|c|c|c|c|c|c|c|}
\hline & \multicolumn{5}{|c|}{ Eastern Africa } & \multicolumn{4}{|c|}{ Southern Africa } & \multicolumn{3}{|c|}{ West Africa } & \multirow{2}{*}{$\begin{array}{c}\begin{array}{c}\text { Southern } \\
\text { Asia }\end{array} \\
\text { India }(\%)\end{array}$} & \multirow{2}{*}{$\begin{array}{c}\text { Southern } \\
\text { Americas } \\
\text { Honduras (\%) }\end{array}$} \\
\hline & $\begin{array}{l}\text { Ethiopia } \\
(\%)\end{array}$ & $\begin{array}{l}\text { Kenya } \\
(\%)\end{array}$ & $\begin{array}{l}\text { Rwanda } \\
(\%)\end{array}$ & $\begin{array}{l}\text { Uganda } \\
(\%)\end{array}$ & $\begin{array}{l}\text { Tanzania } \\
(\%)\end{array}$ & $\begin{array}{l}\text { Zambia } \\
(\%)\end{array}$ & $\begin{array}{l}\text { Malawi } \\
(\%)\end{array}$ & $\begin{array}{l}\text { Mozambique } \\
(\%)\end{array}$ & $\begin{array}{l}\text { Zimbabwe } \\
(\%)\end{array}$ & $\begin{array}{l}\text { Ghana } \\
(\%)\end{array}$ & $\begin{array}{l}\text { Mali } \\
(\%)\end{array}$ & $\begin{array}{l}\text { Niger } \\
(\%)\end{array}$ & & \\
\hline $\begin{array}{l}\text { Infection prevention and } \\
\text { control (IPC) policy } \\
\text { exists for the facility. }\end{array}$ & $58 \pm 4$ & $73 \pm 3$ & $90 \pm 3$ & $73 \pm 3$ & $92 \pm 2$ & $80 \pm 3$ & $56 \pm 4$ & $53 \pm 4$ & $96 \pm 2$ & $71 \pm 3$ & $52 \pm 5$ & $27 \pm 3$ & $62 \pm 3$ & $86 \pm 3$ \\
\hline $\begin{array}{l}\text { Protocol for operation } \\
\text { and management of the } \\
\text { facility, including } \\
\text { procurement of } \\
\text { IPC/WaSH supplies, } \\
\text { exists and is followed. }\end{array}$ & $16 \pm 3$ & $60 \pm 4$ & $85 \pm 4$ & $60 \pm 4$ & $68 \pm 4$ & $56 \pm 4$ & $28 \pm 4$ & $31 \pm 4$ & $73 \pm 4$ & $63 \pm 4$ & $22 \pm 4$ & $11 \pm 2$ & $56 \pm 3$ & $50 \pm 4$ \\
\hline $\begin{array}{l}\text { IPC/WaSH focal person } \\
\text { has been designated for } \\
\text { the facility. }\end{array}$ & $31 \pm 4$ & $67 \pm 4$ & $85 \pm 4$ & $67 \pm 4$ & $56 \pm 4$ & $60 \pm 4$ & $70 \pm 4$ & $55 \pm 4$ & $80 \pm 4$ & $50 \pm 4$ & $37 \pm 4$ & $15 \pm 3$ & $47 \pm 3$ & $58 \pm 4$ \\
\hline $\begin{array}{l}\text { WaSH committee exists } \\
\text { at the facility, and has } \\
\text { met in the past } 6 \text { months. }\end{array}$ & $22 \pm 3$ & $44 \pm 4$ & $79 \pm 5$ & $44 \pm 4$ & $51 \pm 4$ & $39 \pm 4$ & $41 \pm 4$ & $50 \pm 4$ & $45 \pm 4$ & $29 \pm 3$ & $26 \pm 4$ & $12 \pm 2$ & $50 \pm 3$ & $43 \pm 4$ \\
\hline $\begin{array}{l}\text { Community-composed } \\
\text { oversight committee } \\
\text { exists at the facility, and } \\
\text { has met in the past } 6 \\
\text { months. }\end{array}$ & $17 \pm 3$ & $59 \pm 4$ & $88 \pm 4$ & $59 \pm 4$ & $55 \pm 4$ & $69 \pm 3$ & $66 \pm 4$ & $65 \pm 4$ & $71 \pm 4$ & $53 \pm 4$ & $47 \pm 5$ & $23 \pm 3$ & $46 \pm 3$ & $56 \pm 4$ \\
\hline $\begin{array}{l}\text { At least one training on } \\
\text { IPC has been held in the } \\
\text { past year. }\end{array}$ & $88 \pm 3$ & $54 \pm 4$ & $57 \pm 6$ & $54 \pm 4$ & $88 \pm 3$ & $54 \pm 4$ & $36 \pm 5$ & $44 \pm 5$ & $65 \pm 5$ & $63 \pm 4$ & $63 \pm 5$ & $28 \pm 4$ & $94 \pm 2$ & $79 \pm 4$ \\
\hline $\begin{array}{l}\text { WaSH training is } \\
\text { provided for healthcare } \\
\text { providers in the facility. }\end{array}$ & $32 \pm 4$ & $52 \pm 4$ & $42 \pm 6$ & $52 \pm 4$ & $62 \pm 4$ & $43 \pm 4$ & $34 \pm 4$ & $44 \pm 4$ & $61 \pm 1$ & $50 \pm 4$ & $36 \pm 4$ & $23 \pm 3$ & $63 \pm 3$ & $67 \pm 4$ \\
\hline $\begin{array}{l}\text { A sufficient budget has } \\
\text { been allocated for } \\
\text { IPC/WaSH supplies. }\end{array}$ & $6 \pm 2$ & $19 \pm 3$ & $5 \pm 2$ & $18 \pm 3$ & $23 \pm 3$ & $10 \pm 2$ & $39 \pm 2$ & $15 \pm 1$ & $19 \pm 4$ & $7 \pm 2$ & $5 \pm 2$ & $1 \pm 0.1$ & $41 \pm 3$ & $18 \pm 3$ \\
\hline
\end{tabular}

In $64 \%$ of all HCFs where water samples were collected, the sample was in conformity with World Health Organization

(WHO) drinking-water quality guidelines based on Escherichia coli testing (<1 MPN E. coli per 100 mL water) (Table 6). 
Table 6. Proportion of healthcare facilities where water was in conformity with drinking-water quality guidelines (as defined by WHO) at the time of survey, by country. (Point estimates are shown \pm standard error. MPN = "most probable number".)

\begin{tabular}{|c|c|c|c|c|c|c|c|c|c|c|c|c|c|c|}
\hline & \multicolumn{5}{|c|}{ Eastern Africa } & \multicolumn{4}{|c|}{ Southern Africa } & \multicolumn{3}{|c|}{ West Africa } & \multirow{2}{*}{$\begin{array}{l}\begin{array}{c}\text { Southern } \\
\text { Asia }\end{array} \\
\text { India } \\
(\%)\end{array}$} & \multirow{2}{*}{$\begin{array}{l}\text { Southern } \\
\text { Americas } \\
\text { Honduras } \\
(\%)\end{array}$} \\
\hline & $\begin{array}{l}\text { Ethiopia } \\
(\%)\end{array}$ & $\begin{array}{l}\text { Kenya } \\
(\%)\end{array}$ & $\begin{array}{l}\text { Rwanda } \\
(\%)\end{array}$ & $\begin{array}{l}\text { Uganda } \\
(\%)\end{array}$ & $\begin{array}{l}\text { Tanzania } \\
(\%)\end{array}$ & $\begin{array}{l}\text { Zambia } \\
(\%)\end{array}$ & $\begin{array}{l}\text { Malawi } \\
(\%)\end{array}$ & $\begin{array}{l}\text { Mozambique } \\
(\%)\end{array}$ & $\begin{array}{l}\text { Zimbabwe } \\
(\%)\end{array}$ & $\begin{array}{l}\text { Ghana } \\
(\%)\end{array}$ & $\begin{array}{l}\text { Mali } \\
(\%)\end{array}$ & $\begin{array}{l}\text { Niger } \\
(\%)\end{array}$ & & \\
\hline $\begin{array}{l}\text { In conformity } \\
(<1 \mathrm{MPN} E \text {. } \\
\text { coli/100 mL) }\end{array}$ & $73 \pm 5$ & $62 \pm 4$ & $85 \pm 4$ & $62 \pm 4$ & $54 \pm 4$ & $79 \pm 3$ & $81 \pm 4$ & $69 \pm 4$ & $71 \pm 5$ & $52 \pm 4$ & $\begin{array}{l}64 \pm \\
5\end{array}$ & $\begin{array}{l}51 \pm \\
5\end{array}$ & $42 \pm 4$ & $47 \pm 5$ \\
\hline
\end{tabular}

\subsection{Logistic regressions}

Univariable logistic regression within each individual country demonstrated that the following factors had a statistically significant association $(\mathrm{p}<0.05)$ with water quality risk level (Table 7):

Table 7. Factors associated with conformity with drinking-water quality guidelines (as defined by WHO in univariable logistic models, by country.

\begin{tabular}{|c|c|c|c|c|}
\hline Country & Significantly associated factor $(\mathrm{p}<0.05)$ & Odds Ratio & Relationship & Pseudo $\mathrm{R}^{2}$ \\
\hline Kenya & Treatment of water & 2.02 & Factor is protective & 0.0213 \\
\hline \multirow[t]{2}{*}{ Rwanda } & Storage of water & 10.83 & Factor is protective & 0.1125 \\
\hline & Treatment of water & 4.14 & Factor is protective & 0.0609 \\
\hline Tanzania & Storage of water & 4.10 & Factor is protective & 0.0342 \\
\hline \multirow[t]{2}{*}{ Ghana } & WaSH training provided for healthcare professionals & 2.54 & Factor is protective & 0.0383 \\
\hline & Treatment of water & 0.08 & Factor is detrimental & 0.0443 \\
\hline Niger & Average number of patients served by the facility & 1.02 & Factor is protective & 0.0443 \\
\hline Mozambique & Use of an improved water source & 4.60 & Factor is protective & 0.0497 \\
\hline \multirow[t]{2}{*}{ India } & Treatment of water & 1.82 & Factor is protective & 0.0142 \\
\hline & $\begin{array}{l}\text { Existence of an official infection control policy, procedure, or } \\
\text { document for the healthcare facility }\end{array}$ & 0.45 & Factor is detrimental & 0.0257 \\
\hline \multirow[t]{2}{*}{ Honduras } & Storage of water & 3.04 & Factor is protective & 0.0537 \\
\hline & Treatment of water & 2.51 & Factor is protective & 0.0370 \\
\hline
\end{tabular}


In the multivariable mixed-effects logistic regression with the full 14-country dataset (clustered by country) the interclass correlation (ICC) was 0.088 (95\% CI: 0.039, 0.184), meaning that about $9 \%$ of the variance in water quality is attributable to differences across countries instead of HCF-level characteristics. This regression demonstrated that HCFs managed by a person with some level of medical training are at least three times as likely to have safe water than those managed by a person with no medical training. There are no statistically significant differences between the different types of medical training, but the odds ratios for HCFs managed by community health workers/health extension workers $(\mathrm{OR}=5.79)$ and midwives $(\mathrm{OR}=8.98)$ are particularly high. Use of an improved water source is also associated with higher water quality in HCFs. Treatment of water and presence of a protocol for operations and management of the HCF appeared to be associated with safer water quality, although this relationship was only borderline significant at the $95 \%$ confidence level in the multivariable model $(\mathrm{p}=0.074, \mathrm{p}=0.052)($ Table 8$)$. 
Table 8. Factors associated with statistically significant changes in water quality risk level (as defined by WHO), across all 14 aggregated countries in a multivariable logistic model. Overall model $p=0.0030$, based on $n=1,479$, and $\bar{\chi}^{2}$ for LR vs. logistic model <0.0001. Note: Asterisks (*) indicate statistically significant associations at the 95\% confidence level, $p<0.05$.

\begin{tabular}{|l|l|l|}
\hline Variable & Odds Ratio (95\% CI) & p-value \\
\hline Average daily number of patients served by the facility & $1.001(0.999,1.003)$ & 0.111 \\
\hline Facility manager's level of medical training & & \\
None & 1.000 & \\
Doctor & $3.415(0.923,12.558)$ & 0.065 \\
Nurse & $3.686(1.021,13.313)$ & $0.046^{*}$ \\
Community health worker/health extension worker & $5.789(1.335,25.110)$ & $0.019^{*}$ \\
Midwife & $8.977(1.862,43.285)$ & $0.006^{*}$ \\
Other & $4.140(1.123,15.177)$ & $0.032^{*}$ \\
\hline Primary water source type & & \\
Unimproved source & 1.000 & \\
Piped to facility or yard & $1.459(0.970,2.194)$ & 0.070 \\
Borehole (with handpump/pump) & $1.742(1.161,2.613)$ & $0.007 *$ \\
Other improved source & $1.442(0.961,2.164)$ & 0.077 \\
\hline Water treatment at the facility & & \\
No, water is not treated & 1.000 & 0.074 \\
Yes, treated with chlorine, boiling, filtration, etc. & $1.257(0.978,1.616)$ & 0.130 \\
\hline Number of sanitation facilities present & $1.030(0.991,1.071)$ & \\
\hline Presence of a protocol for O\&M of the facility & & \\
Yes, a protocol exists & 1.000 & \\
No, a protocol does not exist & $0.775(0.599,1.002)$ & 0.052 \\
\hline WaSH training for healthcare providers at the facility & & \\
No, healthcare providers are not trained in WaSH & 1.000 & 0.263 \\
Yes, healthcare providers are trained in WaSH & $1.148(0.902,1.461)$ & \\
\hline
\end{tabular}




\section{CHAPTER 5: DISCUSSION}

\subsection{Descriptive analysis}

Overall, the majority of healthcare facilities (HCFs) surveyed were using an improved source of water and had water available at the time of the survey; however, only 3 in 5 HCFs had a main water source on-premises. Because the water source was commonly off-premises in countries such as Ethiopia and Niger, $56 \%$ of the surveyed HCFs used a basic water service, $34 \%$ used a limited water service, and $10 \%$ had no service. Of the 1,292 HCFs who reported that water was stored in a container, $96 \%$ used a container with a lid, but only $62 \%$ reported that water was extracted from the container using a safe method such as dispensing from a spigot, pouring, or scooping with a long-handled ladle. (This varied by country, from $28 \%$ safe extraction in Niger to $99 \%$ safe extraction in Rwanda).

Management and training within HCFs varied widely based on country, with no obvious inter-country trends. The majority of HCFs are working with insufficient funding: only $1 \%$ of HCFs in Niger to $41 \%$ in India reported that they had a budget for the facility which included sufficient funding for $\mathrm{WaSH}$ infrastructure, services, and personnel.

Of the 1,679 HCFs where water samples were collected, only $64 \%$ of HCFs had water in conformity with World Health Organization drinking-water standards (<1 MPN E. coli per 100 mL water). 


\subsection{Influence of water source}

We found that use of an improved water source was associated with safer water quality in the aggregated 14-country dataset. The odds of having uncontaminated water for a HCF with an improved main water source are approximately 1.4 times those of an HCF using an unimproved source, with boreholes performing particularly well. This is a logical extension of current knowledge on water quality: improved water sources are by definition constructed in a way less likely to have fecal contamination, and piped supplies and boreholes tend to outperform other improved sources (R. Bain et al., 2014; K. F. Shields, Bain, Cronk, Wright, \& Bartram, 2015). Note that if the improved source of water is piped directly into the facility or onto the premises, and if it is used directly from the source instead of being collected and later extracted from a container, there are fewer opportunities for contamination of the water.

\subsection{Influence of treatment}

Treatment of water was associated with safer water quality in four countries: Kenya (OR $=2.02)$, Rwanda $(\mathrm{OR}=4.14)$, India $(\mathrm{OR}=1.82)$, and Honduras $(\mathrm{OR}=2.51)$. This relationship was also present, though weaker, in the 14-country aggregate analysis $(\mathrm{OR}=1.26, \mathrm{p}=0.074)$. Again, this is consistent with current knowledge on water quality: treatment by boiling, adding chlorine, filtering, etc. kills or removes bacteria and other microbes.

In one country (Ghana), treatment of water was associated with worse water quality, but this is likely due to collinearity with primary water source type. In Ghana, HCFs with an improved primary water source were more likely to have safe water than HCFs with an unimproved source of water $(\mathrm{OR}=2.43, \mathrm{p}=0.071)$. However, $24 \%$ of HCFs with an unimproved primary water source treated their water, as opposed to $4 \%$ of HCFs with an improved primary water source; this difference was statistically significant $(\mathrm{p}<0.001)$. This 
suggests that, of the $6 \%$ of Ghanaian HCFs where water is treated, the treatment methods are not sufficient for disinfecting the water.

\subsection{Influence of storage}

Univariable regressions demonstrated an association between storage of water and safe water quality in certain countries. In Rwanda, Tanzania, and Honduras, HCFs where water was stored in a container were more likely to have safe water than HCFs where water was not stored. However, this is likely due to collinearity with treatment rather than the effect of storage itself: HCFs where water was stored in a container had the opportunity to treat their water before use, whereas those who used water directly from the source were more likely to be exposed to fecal contamination. Respondents at HCFs where water was stored in a container were more likely to treat their water than respondents at HCFs where water was not stored ( $p<0.001$ in Rwanda and Tanzania, $\mathrm{p}=0.015$ in Honduras).

\subsection{Influence of management and training}

We found that water quality in HCFs is influenced by organizational management and training. In Ghana, WaSH training for healthcare professionals was associated with safer water quality $(\mathrm{OR}=2.54)$. In India, the existence of an infection prevention and control policy at the $\mathrm{HCF}$ was associated with worse water quality $(\mathrm{OR}=0.45)$. In the 14 -country aggregate analysis, we also found that HCFs managed by a person with some medical training (doctor, nurse, health extension worker, etc.) were three to four times as likely to have safe water than HCFs managed by a person with no medical training, and that HCFs with a protocol for operation and management of the facility (including procurement of WaSH supplies) were 1.29 times as likely to have safe water $(\mathrm{p}=0.052)$. 


\subsection{Comparisons to existing literature}

There are few studies of water quality in rural healthcare facilities in low- and middleincome countries: the author is aware of five studies which describe water quality in these settings. One study of drinking-water contamination after a tropical cyclone measured fecal coliforms at numerous sites across Fiji, including four hospitals; samples at one rural hospital had 2 fecal coliforms per $100 \mathrm{~mL}$ water (Mosley, Sharp, \& Singh, 2004). One study described the implementation of an ozone generator used to treat well water in a rural hospital in Colombia; the authors recorded influent water with 10 to 50,000 colony-forming units (CFU) of fecal coliform bacteria per $100 \mathrm{~mL}$, and effluent with 0 to $178 \mathrm{CFU}$ fecal coliform per $100 \mathrm{~mL}$ (Echeverry Ibarra, Cadavid Ramírez, Alonso, Aponte Mayor, \& Gálvis Castaño, 2008). Another study in Rwanda found that in 17 rural HCFs, 10 out of 24 (42\%) of water samples directly from taps met WHO guidelines for E. coli while 15 of 16 (94\%) of treated drinking-water samples met WHO guidelines (Huttinger et al., 2017). Finally, a study by the same authors tracked the performance of ultrafiltration and chlorination treatment systems newly installed in 10 rural HCFs over a 22-month period. The authors found that before intervention, E. coli was detected in $17 \%$ of water samples. During periods where treatment was completely operational, $98 \%$ of samples met WHO guidelines for E. coli (Huttinger et al., 2015). However, estimates of "typical" levels of water contamination in rural HCFs cannot be estimated from these studies: all were collected from groups of 17 or fewer HCFs which were not randomly selected, two of the above studies were evaluations of treatment technologies (ozone, ultrafiltration) which are not commonly used in HCF in rural areas of LMIC, and one documented atypical conditions after a natural disaster. 
One other study exists which documents water quality in rural HCF within Uganda and Mozambique (Guo et al., 2017). The study, conducted in 2014, found that $30 \%$ of water samples in Mozambique were contaminated with E. coli, similar to the $31 \%$ in this study. In $2014,15.3 \%$ of water samples in Uganda were contaminated with E. coli, as compared to $38 \%$ in this study. This discrepancy may be due to slight differences in the subnational regions covered in Uganda in both studies, as well as differing sample sizes ( $\mathrm{n}=144$ in 2014 study, vs. $\mathrm{n}=68$ in this study). However, Guo et al. only presented descriptive statistics on water quality and did not evaluate predictors of water quality.

\subsection{Limitations}

The results of this study may be affected by several limitations. Firstly, the crosssectional design of the study means that we were not able to establish causality (although we were able to demonstrate a correlation between these factors and changes in water quality), and we were also unable to gauge effects such as seasonality. These data were also subject to social desirability bias and non-response bias, although we tried to limit bias and variability by using a standardized format to ask the questions and training all enumerators on impartial interview technique. Furthermore, since water samples were only taken at HCFs where water was available at the time of the survey, the water quality results may underrepresent HCFs with intermittent or unreliable water service, which are more likely to have contaminated water.

In this study, water quality was measured with a single water sample tested for E. coli at each HCF. This is a moderate indicator of actual water safety, but does not encompass all aspects of safety, including chemical contaminants and microbial contaminants other than bacteria, as well as safety over time. While we have presented statistically significant (or borderline statistically significant) relationships, we should note that the pseudo- $\mathrm{R}^{2}$ value for all of the 
univariate regressions were low, with the largest $\mathrm{R}^{2}$ value only 0.1125 . This indicates that most of the variability in water quality is still unexplained by the variables we tested. Some of this variability might result from noise in the data, as measurements of E. coli can vary widely by day and time of day even when taken from the same source. Additionally, variability might be explained by other factors such as country (which accounted for $9 \%$ of variability based on our regression model), seasonality, water point characteristics, proximity to cities, or natural variation in water quality over time.

\subsection{Takeaways}

This study is the largest known study of WaSH in rural HCFs in LMIC. It provides descriptive information on the status of water service levels for over 2,000 HCFs in 14 countries. To our knowledge, this is also the first study which identifies predictors of water quality in these settings. It confirms that some factors that influence water quality in the household setting (use of an improved water source and water treatment) are also applicable in HCFs, and identifies new areas in organization and management of HCFs (hiring of facility managers with medical background, preparation of an operations and maintenance plan for the facility) that can be targeted in order to improve water quality in HCFs. 


\section{CHAPTER 6: CONCLUSIONS}

A safe water supply is necessary for healthcare facilities (HCFs) in order to provide clean water, and to maintain a hygienic environment that both patients and staff can trust.

Understanding the predictors of water quality in HCFs may help stakeholders such as government officials, local and international non-governmental organizations (NGOs), HCF administrators, and researchers when planning programs and identifying opportunities for improving water quality in HCFs.

We found that use of an improved water source was associated with improved water quality in HCFs. HCFs who boiled, chlorinated, filtered, or otherwise treated their water were also more likely to have "safe" water. Based on this information, NGOs, government officials, and other program implementers should continue increasing access to improved sources of water. Though the majority of HCFs have access to an improved source of water, $14 \%$ of $\mathrm{HCFs}$ remain without improved water; these may be HCFs that are particularly remote or otherwise hard to reach, and they may require new strategies and/or increased intensity of effort to be provided with an improved water source. The same groups should also continue to promote water treatment in HCFs, especially in areas where source water quality is poor.

We also demonstrated that existence of a protocol for operations and management of the HCF and management of HCFs by a person with medical training are associated with safer water quality. HCF administrators might consider incorporating these elements into their HCFs by hiring people with $\mathrm{WaSH}$ and medical knowledge to manage HCF operations, as well as creating 
official policies for regularly procuring $\mathrm{WaSH}$ for the facility. For government officials who are are compiling any rules or 'best practices' in WaSH or management of HCFs, these two elements could be incorporated.

Finally, researchers investigating water quality in HCFs might consider changing aspects of our existing study design - for instance, increasing the number of samples taken from each $\mathrm{HCF}$, measuring for other types of contaminants such as viruses and protozoa, or using a longitudinal design rather than a cross-sectional design - in order to reduce variability and noise in the data.

While some factors which influence water quality (country) are not modifiable, some of the other predictors of water quality identified in this study can be changed in order to increase the likelihood that a HCF uses water in conformity with WHO guidelines for E. coli. Overall, we found that water source and water treatment, which have been identified in other settings such as households, are also relevant in HCFs. Additional organizational factors such as institutional policy and manager training can also be targeted to improve water quality. 
APPENDIX: FULL HEALTHCARE FACILITY QUESTIONNAIRE

\section{World Vision 14-Country Evaluation: Healthcare Facility Survey Master Copy}

\subsection{Metadata}

If the head doctor is available, interview this person. If he/she is not available, interview the head nurse. If this person is not available, a nurse at the health center who has worked there for more than 2 years can be interviewed.

0.01 [For Enumerator] Country

$\square$ Ethiopia

$\square$ Kenya

$\square$ Rwanda

$\square$ Uganda

$\square$ Tanzania

$\square$ Ghana

$\square$ Mali

$\square$ Niger

$\square$ Zambia

$\square$ Malawi

$\square$ Mozambique

$\square$ Zimbabwe

$\square$ India

$\square$ Honduras

0.02 [For Enumerator] 1st administrative district

$\square$ Not Applicable

0.03 [For Enumerator] 2nd administrative district

CC BY-SA 2017, The Water Institute at UNC 
$\square$ Not Applicable

0.04 [For Enumerator] 3rd administrative district

Hint: Do not capitalize

$\square$ Not Applicable

[For Enumerator] 4th Administrative District

Hint: Capitalize first letter only

$\square$ Not Applicable

0.05 [For Enumerator] Community/village

Hint: Do not capitalize

0.06 [For Enumerator] Health facility name

0.08 [For Enumerator] Visit to Health Center

$\square$ 1st Visit

$\square$ 2nd Visit

$\square$ 3rd Vist

$\square$ 4th Visit

0.09 [For Enumerator] Day of the week

$\square$ Monday

$\square$ Tuesday

$\square$ Wednesday

$\square$ Thursday

$\square$ Friday

$\square$ Saturday

$\square$ Sunday

CC BY-SA 2017, The Water Institute at UNC 


\subsection{1 [For Enumerator] Enumerator name}

0.12 [For Enumerator] Is an eligible respondent available to do the interview?

$\square$ Yes

$\square$ No

If 0.12 [For Enumerator] Is an eligible respondent available to do the interview? is Yes:

0.13 [For Enumerator] Is the head doctor, head nurse, or eligible nurse available for the survey?

$\square$ Yes, head doctor

$\square$ Yes, head nurse

$\square$ Yes, nurse who has worked at facility for $>2$ years

$\square$ No

$\square$ Other (please specify)

If 0.12 [For Enumerator] Is an eligible respondent available to do the interview? is No:

0.14 [For Enumerator] Why is no eligible person available for the survey?

$\square$ No one at health center

$\square$ Unoccupied/Vacant/Demolished Health Center

$\square$ Selected address is not a health center

$\square$ No eligible respondent at facility

$\square$ Other (please specify)

If 0.13 [For Enumerator] Is the head doctor, head nurse, or eligible nurse available for the survey? is No:

0.15 [For Enumerator] Notes for best time to return

0.16 [For Enumerator] GPS of HCF

0.17 [For Enumerator] Has informed consent been obtained?

CC BY-SA 2017, The Water Institute at UNC 
$\square$ Yes

$\square$ No

If 0.17 [For Enumerator] Has informed consent been obtained? is Yes:

\section{HEALTH FACILITY DATA}

1.02. [For Respondent] Type of facility (circle one)

$\square$ Health Post

$\square$ Health Center

$\square$ Private Clinic

$\square$ Sub Centre

$\square$ Primary Health Center

$\square$ Community Health Center/ Block Health Center

$\square$ Other (please specify)

1.03. What is the average number of patients served each day by this facility?

\section{Don't Know}

$\square$ Not Applicable

1.04. How many examination rooms or points of care does this facility have?

Don't Know

$\square$ Not Applicable

1.05. Does this facility conduct maternity services including deliveries?

$\square$ Yes

$\square$ No

$\square$ Decline to state

Don't Know

1.06. a. What is the name of the person responsible for managing this health facility?

CC BY-SA 2017, The Water Institute at UNC 
Don't Know

$\square$ Not Applicable

1.06. b. What is this health facility manager's level of medical training?

$\square$ Doctor

$\square$ Nurse

$\square$ None

$\square$ Other (please specify)

\section{$\square$ Decline to state}

Don't Know

1.07: How many pregnant patients did the facility receive last week?

\section{Don't Know}

$\square$ Not Applicable

1.09: How many children under the age of five did the facility receive last week?

\section{Don't Know}

$\square$ Not Applicable

If 1.05. Does this facility conduct maternity services including deliveries? is Yes:

5.01. How many women (on average) are served by the maternity personnel each day?

\section{$\square$ Don't Know}

\section{$\square$ Not Applicable}

If 5.01. How many women (on average) are served by the maternity personnel each day? (magnitude) is greater than 0:

5.02. How many deliveries occur per week at the health facility?

$\square$ Don't Know

$\square$ Not Applicable

If 0.17 [For Enumerator] Has informed consent been obtained? is Yes:

CC BY-SA 2017, The Water Institute at UNC 


\section{ACCESS TO SAFE WATER}

2.01.What is the main (most often used) water point type used by this health facility? (Check box next to the appropriate category.)

$\square$ Piped water into facility

$\square$ Piped water into yard

$\square$ Public tap

$\square$ Borehole (with handpump/pump)

$\square$ Protected dug well (closed)

$\square$ Unprotected dug well (open)

$\square$ Protected spring (closed)

$\square$ Unprotected spring (open)

$\square$ Rainwater collection

$\square$ Water-selling cart or truck

$\square$ Surface water

$\square$ Bottled water or sachet

$\square$ Other (please specify)

2.02.Where is the main water point for the facility?

$\square$ On premises

$\square$ Within $500 \mathrm{~m}$

$\square$ Further than $500 \mathrm{~m}$

$\square$ No water source available

$\square$ Don't Know

$\square$ Decline to state

If 2.02. Where is the main water point for the facility? isn't No water source available:

2.03. Is water available from the main water point right now? (If on premises, observe if water is available)

$\square$ Yes, observed

$\square$ Yes, reported but not observed

$\square$ No

CC BY-SA 2017, The Water Institute at UNC 
Decline to state

\section{Don't Know}

2.04.Does this health facility store drinking water in a container?

Hint: If no, ask to take a water sample from their main water point. If yes, ask the respondent to see the container.

$\square$ Yes

$\square$ No

$\square$ Decline to state

$\square$ Don't Know

If 2.04.Does this health facility store drinking water in a container? is Yes:

2.05. [Observe] Type(s) of container(s) used to store water. (Check box next to any that apply.)

$\square$ Narrow opening container

$\square$ Wide opening container

$\square$ Container with spigot/tap

$\square$ Other (please specify)

If 2.04.Does this health facility store drinking water in a container? is Yes:

2.06. [Observe] Does the health facility's water storage container have a lid that completely covers it?

$\square$ Yes

$\square$ No

If 2.04.Does this health facility store drinking water in a container? is Yes:

2.07. Can you show me how you would normally take water for drinking? (Check box next to any that apply.) (Use this water for the microbial water test)

Hint: (Mark only the options that are directly used to remove water from the container. For example, if water is ladled out of a container and later poured into a bowl, you should only mark "Dipper or ladle" here.)

$\square$ Water poured directly from container

$\square$ Dispensed through a spigot or spout

$\square$ Removed with jar, bowl, bucket, or cup

CC BY-SA 2017, The Water Institute at UNC 


\section{$\square$ Removed with dipper or ladle}

$\square$ Removed with hands

$\square$ Other (please specify)

\section{$\square$ Don't know}

$\square$ Decline to state

[For Enumerator] Take a picture of the container or water point where the respondent served you water from.

$\square$ Not Applicable

2.07b Scan the bar code of the microbial water sample.

\section{$\square$ Not Applicable}

If 2.07b Scan the bar code of the microbial water sample. is Not Applicable: Take a picture of the microbial sample barcode

If 2.07b Scan the bar code of the microbial water sample. is Not Applicable:

2.17b Enter the barcode number

$\square$ Not Applicable

[For Enumerator] Are you taking a sample duplicate?

$\square$ Yes

$\square$ No

If [For Enumerator] Are you taking a sample duplicate? is Yes:

Scan the barcode of the sample duplicate

\section{$\square$ Not Applicable}

If [For Enumerator] Are you taking a sample duplicate? is Yes:

2.17b Enter the barcode number

Hint: You may enter NA if the barcode scanned properly

CC BY-SA 2017, The Water Institute at UNC 
$\square$ Not Applicable

[For Enumerator] Are you taking a sample blank?

$\square$ Yes

$\square$ No

If [For Enumerator] Are you taking a sample blank? is Yes:

Scan the barcode of the sample blank

$\square$ Not Applicable

If [For Enumerator] Are you taking a sample blank? is Yes:

2.17b Enter the barcode number

Hint: You may enter NA if the barcode scanned properly

$\square$ Not Applicable

2.08. Does the health facility do anything to the water to 'make it safer?'

$\square$ Yes

$\square$ No

$\square$ Decline to state

Don't Know

If 2.08. Does the health facility do anything to the water to 'make it safer?' is Yes:

2.09. What do you do to make the water safer? (Check boxes next to all that apply.)

$\square$ Boiling

$\square$ Chlorine (liquid, powder, or tablets)

$\square$ Filtration with a cloth

$\square$ Ceramic filter

$\square$ Other (please specify)

Decline to state

Don't Know

CC BY-SA 2017, The Water Institute at UNC 
2.10. Does the main water point operate continuously?

Hint: (A continuous water supply means that water is available to the health facility 24 hours a day)

$\square$ Yes

$\square$ No

$\square$ Decline to state

Don't Know

If 2.10. Does the main water point operate continuously? is No:

2.11. Does the health facility's water point provide service at fixed times?

Hint: Scheduled water service is service that provides water at designated times of the day on a schedule.

$\square$ Yes

$\square$ No

$\square$ Decline to state

Don't Know

If 2.10. Does the main water point operate continuously? is No:

2.12. How many hours per week does the health facility receive water?

Don't Know

$\square$ Not Applicable

2.13. Has the health facility's primary (main, most often used) water point been out of service in the past two weeks?

$\square$ Yes

$\square$ No

$\square$ Decline to state

\section{Don't Know}

If 2.13. Has the health facility's primary (main, most often used) water point been out of service in the past two weeks? is Yes:

2.14. How many times was the primary water point out of service in the past two weeks?

Don't Know

CC BY-SA 2017, The Water Institute at UNC 
$\square$ Not Applicable

2.15. Is water at this facility accessible for people with reduced mobility? (either water source or storage container)

$\square$ Yes

$\square$ No

$\square$ Decline to state

$\square$ Don't Know

If 2.15. Is water at this facility accessible for people with reduced mobility? (either water source or storage container) is No:

2.16. What are the reasons why the water is not accessible for people with reduced mobility?

[Do not read the answers aloud. Mark all that apply]

$\square$ Water point is far from the health facility

$\square$ Path to water point/storage container is difficult to navigate

$\square$ Pump or water tap superstructure is difficult to access or traverse

$\square$ Water taps or pumps are difficult to manipulate

$\square$ Location of water container is inaccessible

$\square$ Water container is too heavy to lift or carry

$\square$ Visual impairment hinders use of the water container

$\square$ Unable to grasp or balance the container

$\square$ Not allowed or discouraged by staff or household members to access/manipulate water

$\square$ No one available to help them access water

$\square$ Embarrassed/ashamed to fetch water at the water point

$\square$ Other (please specify)

$\square$ Decline to state

Don't Know

2.17. Does the health facility use any sources for drinking water other than the primary water point?

$\square$ Yes

CC BY-SA 2017, The Water Institute at UNC 
$\square$ No

Decline to state

$\square$ Don't Know

If 2.17. Does the health facility use any sources for drinking water other than the primary water point? is Yes: 2.18. What other source(s) of drinking water does the health facility use? (Check box next to the appropriate category.)

$\square$ Piped water into dwelling

$\square$ Piped water into yard

$\square$ Public tap

$\square$ Borehole (with handpump/pump)

$\square$ Protected dug well (closed)

$\square$ Unprotected dug well (open)

$\square$ Protected spring (closed)

$\square$ Unprotected spring (open)

$\square$ Rainwater collection

$\square$ Water-selling cart or truck

$\square$ Surface water

$\square$ Bottled water or sachet

$\square$ Other (please specify)

\section{Decline to state}

Don't Know

If 2.17. Does the health facility use any sources for drinking water other than the primary water point? is Yes:

2.19 Where is the closest alternative water source that this health facility uses?

$\square$ On premises

$\square$ Within $500 \mathrm{~m}$

$\square$ Further than $500 \mathrm{~m}$

$\square$ Decline to state

$\square$ Don't Know

CC BY-SA 2017, The Water Institute at UNC 
If 2.17. Does the health facility use any sources for drinking water other than the primary water point? is Yes: 2.20. Does the health facility's closest alternative water point have a continuous supply of water?

Hint: (A continuous water supply means that water is available to the health facility 24 hours a day)

$\square$ Yes

$\square$ No

$\square$ Decline to state

$\square$ Don't Know

If 0.17 [For Enumerator] Has informed consent been obtained? is Yes:

\section{ACCESS TO SANITATION}

3.00. Does the health facility have access to its own sanitation facilities?

$\square$ Yes

$\square$ No

$\square$ Decline to state

Don't Know

3. 01.How many sanitation facilities are at/in this health facility? Hint: Count each toilet or pit or drop hole

\section{Don't Know}

$\square$ Not Applicable

If 3.01. How many sanitation facilities are at/in this health facility? is greater than 0 :

3.02. How many of the sanitation facilities are being used?

Don't Know

3.03. Is there open defecation at this facility?

$\square$ Yes

$\square$ No

$\square$ Decline to state

CC BY-SA 2017, The Water Institute at UNC 


\section{Don't Know}

Ask the respondent to take you to each of the sanitation facilities at the health facility and answer the following questions for each sanitation facility.

Toilet 1

3.04. [Observe] What type of sanitation facility is this?

$\square$ Flush toilet to piped sewer system

$\square$ Flushed toilet to septic tank

Flushed toilet to pit latrine (single or twin)

$\checkmark$ Flushed toilet to elsewhere (e.g. river, surface, etc.)

$\square$ Ventilated improved pit latrine (VIP)

$\square$ Pit latrine with slab

$\square$ Pit latrine without slab

$\square$ Composting toilet

Bucket

Hanging toilet

$\square$ Community latrines

$\square$ Other (please specify)

3.18. Is this sanitation facility designated for women and girls only?

$\square$ Yes

$\square$ No

$\square$ Decline to state

$\square$ Don't Know

3.20. Is this sanitation facility designated for staff only?

$\square$ Yes

$\square$ No

CC BY-SA 2017, The Water Institute at UNC 


\section{Decline to state}

\section{Don't Know}

3.05 [For enumerator] Take a picture of the sanitation facility.

Not Applicable

3.11 [Observe] Does the sanitation facility have a superstructure?

Yes, with roof

$\square$ Yes, no roof

No

If 3.11 [Observe] Does the sanitation facility have a superstructure? is one of Yes, with roof, Yes, no roof: 3.06. [Observe] Does this sanitation facility have a door which is unlocked (If unsure, ask if a key is available at any time)?

$\square$ Yes

No, key is always available

$\square$ No, key is not always available

No door

If 3.06. [Observe] Does this sanitation facility have a door which is unlocked (If unsure, ask if a key is available at any time)? is one of Yes, No, key is always available, No, key is not always available:

3.07. [Observe] Can the door be closed and locked from the inside?

$\square$ Yes

$\square$ No

3.08. [Observe] Are there barriers on the path, opening, or hole/pit for the sanitation facility that block entry or use.

$\square$ Yes

$\square$ No

If 3.11 [Observe] Does the sanitation facility have a superstructure? is one of Yes, with roof, Yes, no roof: 3.12.[Observe] Does the sanitation facility have any major holes in the super-structure that allow someone to see through it?

$\square$ Yes

$\square$ No

CC BY-SA 2017, The Water Institute at UNC 
3.09.[Observe] What type of flooring/slab does this sanitation facility have?
Concrete
Boards/planks
Plastic
Sticks and/or mud
$\square$ No floor/slab (open pit)
$\square$ Other (please specify)

3.10 [Observe] Do you observe any of the following in the sanitation facility? Mark all that apply: $\square$ Unstable slab

$\square$ Pit too big

$\square$ Pit caving in

$\square$ Pit full or overflowing

$\square$ Slab/toilet cracked or broken

$\square$ Facility flooded

$\square$ Bad smell

$\square$ None

3.14. [Observe] Is there a lid covering the hole/slab?

$\square$ Yes

$\square$ No

3.13 [Observe] Are culturally appropriate anal cleansing materials currently available at this sanitation facility?

$\square$ Yes

$\square$ No

3.17 [Observe] Is there functional lighting in this sanitation facility?

$\square$ Yes

$\square$ No

3.15. [Observe] Are feces present on the floor, slab, or walls?

CC BY-SA 2017, The Water Institute at UNC 
Feces present, floor is wet

Feces present, floor is dry

No feces, floor is wet

No feces, floor is dry

3.16. [Observe] Are there flies present?

$\square$ Yes, more than 10

$\square$ Yes, less than 10

$\square$ No

3.19. [Observe] Which of the following is this sanitation facility equipped with? (Check box next to any that apply.)

a bin with a lid on it within the cubicle

water

soap

private space for washing

$\square$ None

3.22. [Observe] Does the sanitation facility have any of the following characteristics that would make it difficult for people with limited mobility to use?

Path to toilet is difficult to navigate

Stairs or steps at the threshold/entrance to the facility

$\square$ No handrails or support on the floor or sidewalls

$\square$ The door is less than $80 \mathrm{~cm}$ wide and/or opens inward

$\square$ The door handles cannot be gripped easily or are too high or low to reach $\square$ There is no seating for persons who are unable to squat, or the existing seat is not easily accessible (too high or too low)

$\square$ Insufficient space inside for a wheelchair user to enter and park by the toilet/latrine

\section{None}

3.23 Is there an additional sanitation facility? If yes, ask if they can take you to it. Hint: If yes, ask if they can take you to the next toilet.

CC BY-SA 2017, The Water Institute at UNC 
$\square$ Yes

$\square$ No

If 3.23 Is there an additional sanitation facility? If yes, ask if they can take you to it. is Yes:

\section{Toilet 2}

3.04a. [Observe] What type of sanitation facility is this?

$\square$ Flush toilet to piped sewer system

$\square$ Flushed toilet to septic tank

$\square$ Flushed toilet to pit latrine (single or twin)

$\checkmark$ Flushed toilet to elsewhere (e.g. river, surface, etc.)

$\square$ Ventilated improved pit latrine (VIP)

$\square$ Pit latrine with slab

$\square$ Pit latrine without slab

$\square$ Composting toilet

$\square$ Bucket

$\square$ Hanging toilet

Community latrines

Other (please specify)

3.18 a Is this sanitation facility designated for women and girls only?

$\square$ Yes

$\square$ No

$\square$ Decline to state

$\square$ Don't Know

$3.20 a$ Is this sanitation facility designated for staff only?

$\square$ Yes

$\square$ No

$\square$ Decline to state

$\square$ Don't Know

CC BY-SA 2017, The Water Institute at UNC 
3.05a [For enumerator] Take a picture of the sanitation facility.

$\square$ Not Applicable

3.11a [Observe] Does the sanitation facility have a superstructure?

$\square$ Yes, with roof

$\square$ Yes, no roof

No

If 3.11a [Observe] Does the sanitation facility have a superstructure? is one of Yes, with roof, Yes, no roof: 3.06a [Observe] Does this sanitation facility have a door which is unlocked (If unsure, ask if a key is available at any time)?

Yes

No, key is always available

No, key is not always available

No door

If 3.06a [Observe] Does this sanitation facility have a door which is unlocked (If unsure, ask if a key is available at any time)? is one of Yes, No, key is always available, No, key is not always available:

3.07a [Observe] Can the door be closed and locked from the inside?

$\square$ Yes

$\square$ No

3.08a [Observe] Are there barriers on the path, opening, or hole/pit for the sanitation facility that block entry or use.

$\square$ Yes

$\square$ No

If 3.11 [Observe] Does the sanitation facility have a superstructure? is one of Yes, with roof, Yes, no roof: $3.12 a$ [Observe] Does the sanitation facility have any major holes in the super-structure that allow someone to see through it?

$\square$ Yes

No

3.09a [Observe] What type of flooring/slab does this sanitation facility have?

CC BY-SA 2017, The Water Institute at UNC 
$\square$ Concrete

Boards/planks

Plastic

Sticks and/or mud

No floor/slab (open pit)

$\square$ Other (please specify)

3.10a [Observe] Do you observe any of the following in the sanitation facility? Mark all that apply: $\square$ Unstable slab

$\square$ Pit too big

$\square$ Pit caving in

$\square$ Pit full or overflowing

Slab/toilet cracked or broken

$\checkmark$ Facility flooded

Bad smell

$\square$ None

3.14a [Observe] Is there a lid covering the hole/slab?

$\square$ Yes

$\square$ No

3.13a [Observe] Are culturally appropriate anal cleansing materials currently available at this sanitation facility?

$\square$ Yes

$\square$ No

3.17a [Observe] Is there functional lighting in this sanitation facility?

$\square$ Yes

$\square$ No

3.15a [Observe] Are feces present on the floor, slab, or walls?

$\square$ Feces present, floor is wet

CC BY-SA 2017, The Water Institute at UNC 
Feces present, floor is dry

No feces, floor is wet

No feces, floor is dry

3.16a [Observe] Are there flies present?

Yes, more than 10

$\square$ Yes, less than 10

No

3.19a [Observe] Which of the following is this sanitation facility equipped with? (Check box next to any that apply.)

$\square$ a bin with a lid on it within the cubicle

water

soap

private space for washing

None

3.22a [Observe] Does the sanitation facility have any of the following characteristics that would make it difficult for people with limited mobility to use?

$\square$ Path to toilet is difficult to navigate

$\square$ Stairs or steps at the threshold/entrance to the facility

$\square$ No handrails or support on the floor or sidewalls

The door is less than $80 \mathrm{~cm}$ wide and/or opens inward

$\square$ The door handles cannot be gripped easily or are too high or low to reach $\square$ There is no seating for persons who are unable to squat, or the existing seat is not easily accessible (too high or too low)

$\square$ Insufficient space inside for a wheelchair user to enter and park by the toilet/latrine

None

3.23a Is there an additional sanitation facility? If yes, ask if they can take you to it. Hint: If yes, ask if they can take you to the next toilet.

$\square$ Yes

CC BY-SA 2017, The Water Institute at UNC 
$\square$ No

If $3.23 a$ Is there an additional sanitation facility? If yes, ask if they can take you to it. is Yes:

\section{Toilet 3}

3.04b [Observe] What type of sanitation facility is this?

$\square$ Flush toilet to piped sewer system

$\square$ Flushed toilet to septic tank

$\square$ Flushed toilet to pit latrine (single or twin)

$\square$ Flushed toilet to elsewhere (e.g. river, surface, etc.)

Ventilated improved pit latrine (VIP)

$\square$ Pit latrine with slab

$\square$ Pit latrine without slab

$\square$ Composting toilet

$\square$ Bucket

$\square$ Hanging toilet

$\square$ Community latrines

$\square$ Other (please specify)

$3.18 \mathrm{~b}$ Is this sanitation facility designated for women and girls only?

$\square$ Yes

$\square$ No

$\square$ Decline to state

$\square$ Don't Know

$3.20 \mathrm{~b}$ Is this sanitation facility designated for staff only?

$\square$ Yes

$\square$ No

Decline to state

Don't Know

3.05b [For enumerator] Take a picture of the sanitation facility.

CC BY-SA 2017, The Water Institute at UNC 
$\square$ Not Applicable

3.11b [Observe] Does the sanitation facility have a superstructure?

$\square$ Yes, with roof

$\square$ Yes, no roof

$\square$ No

If $3.11 \mathrm{~b}$ [Observe] Does the sanitation facility have a superstructure? is one of Yes, with roof, Yes, no roof: 3.06b [Observe] Does this sanitation facility have a door which is unlocked (If unsure, ask if a key is available at any time)?

\section{Yes}

No, key is always available

No, key is not always available

No door

If 3.06b [Observe] Does this sanitation facility have a door which is unlocked (If unsure, ask if a key is available at any time)? is one of Yes, No, key is always available, No, key is not always available:

3.07b [Observe] Can the door be closed and locked from the inside?

$\square$ Yes

$\square$ No

3.08b [Observe] Are there barriers on the path, opening, or hole/pit for the sanitation facility that block entry or use.

$\square$ Yes

$\square$ No

If $3.11 \mathrm{~b}$ [Observe] Does the sanitation facility have a superstructure? is one of Yes, with roof, Yes, no roof: 3.12b [Observe] Does the sanitation facility have any major holes in the super-structure that allow someone to see through it?

$\square$ Yes

No

3.09b [Observe] What type of flooring/slab does this sanitation facility have?

Concrete

CC BY-SA 2017, The Water Institute at UNC 
$\square$ Boards/planks

Plastic

$\square$ Sticks and/or mud

$\square$ No floor/slab (open pit)

$\square$ Other (please specify)

3.10b [Observe] Do you observe any of the following in the sanitation facility? Mark all that apply: $\square$ Unstable slab

Pit too big

Pit caving in

$\square$ Pit full or overflowing

$\square$ Slab/toilet cracked or broken

$\square$ Facility flooded

$\square$ Bad smell

$\square$ None

3.14b [Observe] Is there a lid covering the hole/slab?

$\square$ Yes

$\square$ No

3.13b [Observe] Are culturally appropriate anal cleansing materials currently available at this sanitation facility?

$\square$ Yes

$\square$ No

3.17b [Observe] Is there functional lighting in this sanitation facility?

$\square$ Yes

$\square$ No

3.15b [Observe] Are feces present on the floor, slab, or walls?

Feces present, floor is wet

Feces present, floor is dry

CC BY-SA 2017, The Water Institute at UNC 
$\square$ No feces, floor is wet

No feces, floor is dry

3.16b [Observe] Are there flies present?

Yes, more than 10

$\square$ Yes, less than 10

No

3.19b [Observe] Which of the following is this sanitation facility equipped with? (Check box next to any that apply.)

a bin with a lid on it within the cubicle

$\square$ water

soap

private space for washing

$\square$ None

3.22b [Observe] Does the sanitation facility have any of the following characteristics that would make it difficult for people with limited mobility to use?

$\square$ Path to toilet is difficult to navigate

$\square$ Stairs or steps at the threshold/entrance to the facility

$\square$ No handrails or support on the floor or sidewalls

$\square$ The door is less than $80 \mathrm{~cm}$ wide and/or opens inward

$\square$ The door handles cannot be gripped easily or are too high or low to reach $\square$ There is no seating for persons who are unable to squat, or the existing seat is not easily accessible (too high or too low)

$\square$ Insufficient space inside for a wheelchair user to enter and park by the toilet/latrine

None

3.23b Is there an additional sanitation facility? If yes, ask if they can take you to it. Hint: If yes, ask if they can take you to the next toilet.

$\square$ Yes

$\square$ No

CC BY-SA 2017, The Water Institute at UNC 
If $3.23 \mathrm{~b}$ Is there an additional sanitation facility? If yes, ask if they can take you to it. is Yes:

Toilet 4

3.04c [Observe] What type of sanitation facility is this?

Flush toilet to piped sewer system

Flushed toilet to septic tank

Flushed toilet to pit latrine (single or twin)

$\square$ Flushed toilet to elsewhere (e.g. river, surface, etc.)

$\square$ Ventilated improved pit latrine (VIP)

$\square$ Pit latrine with slab

$\square$ Pit latrine without slab

$\square$ Composting toilet

$\square$ Bucket

$\square$ Hanging toilet

$\square$ Community latrines

$\square$ Other (please specify)

$3.18 \mathrm{c}$ Is this sanitation facility designated for women and girls only?

$\square$ Yes

$\square$ No

$\square$ Decline to state

$\square$ Don't Know

3.20c Is this sanitation facility designated for staff only?

$\square$ Yes

$\square$ No

Decline to state

$\square$ Don't Know

3.05c [For enumerator] Take a picture of the sanitation facility.

CC BY-SA 2017, The Water Institute at UNC 
$\square$ Not Applicable

3.11c [Observe] Does the sanitation facility have a superstructure?

$\square$ Yes, with roof

$\square$ Yes, no roof

No

If 3.11c [Observe] Does the sanitation facility have a superstructure? is one of Yes, with roof, Yes, no roof: 3.06c [Observe] Does this sanitation facility have a door which is unlocked (If unsure, ask if a key is available at any time)?

Yes

No, key is always available

No, key is not always available

No door

If 3.06c [Observe] Does this sanitation facility have a door which is unlocked (If unsure, ask if a key is available at any time)? is one of Yes, No, key is always available, No, key is not always available:

3.07c [Observe] Can the door be closed and locked from the inside?

$\square$ Yes

$\square$ No

3.08c [Observe] Are there barriers on the path, opening, or hole/pit for the sanitation facility that block entry or use.

$\square$ Yes

No

If 3.11c [Observe] Does the sanitation facility have a superstructure? is one of Yes, with roof, Yes, no roof: 3.12c [Observe] Does the sanitation facility have any major holes in the super-structure that allow someone to see through it?

$\square$ Yes

$\square$ No

3.09c [Observe] What type of flooring/slab does this sanitation facility have?

Concrete

Boards/planks

CC BY-SA 2017, The Water Institute at UNC 
Plastic

Sticks and/or mud

$\square$ No floor/slab (open pit)

$\square$ Other (please specify)

3.10c [Observe] Do you observe any of the following in the sanitation facility? Mark all that apply: $\square$ Unstable slab

$\square$ Pit too big

$\square$ Pit caving in

$\square$ Pit full or overflowing

$\square$ Slab/toilet cracked or broken

$\square$ Facility flooded

$\square$ Bad smell

$\square$ None

3.14c [Observe] Is there a lid covering the hole/slab?

$\square$ Yes

$\square$ No

3.13c [Observe] Are culturally appropriate anal cleansing materials currently available at this sanitation facility?

$\square$ Yes

$\square$ No

3.17c [Observe] Is there functional lighting in this sanitation facility?

$\square$ Yes

$\square$ No

3.15c [Observe] Are feces present on the floor, slab, or walls?

Feces present, floor is wet

Feces present, floor is dry

No feces, floor is wet

CC BY-SA 2017, The Water Institute at UNC 
$\square$ No feces, floor is dry

3.16c [Observe] Are there flies present?

$\square$ Yes, more than 10

$\square$ Yes, less than 10

No

3.19c [Observe] Which of the following is this sanitation facility equipped with? (Check box next to any that apply.)

a bin with a lid on it within the cubicle

water

soap

private space for washing

$\square$ None

3.22c [Observe] Does the sanitation facility have any of the following characteristics that would make it difficult for people with limited mobility to use?

Path to toilet is difficult to navigate

$\square$ Stairs or steps at the threshold/entrance to the facility

$\square$ No handrails or support on the floor or sidewalls

$\square$ The door is less than $80 \mathrm{~cm}$ wide and/or opens inward

$\square$ The door handles cannot be gripped easily or are too high or low to reach $\square$ There is no seating for persons who are unable to squat, or the existing seat is not easily accessible (too high or too low)

$\square$ Insufficient space inside for a wheelchair user to enter and park by the toilet/latrine

$\square$ None

$3.23 \mathrm{c}$ Is there an additional sanitation facility? If yes, ask if they can take you to it. Hint: If yes, ask if they can take you to the next toilet.

$\square$ Yes

$\square$ No

If $3.23 \mathrm{c}$ Is there an additional sanitation facility? If yes, ask if they can take you to it. is Yes:

CC BY-SA 2017, The Water Institute at UNC 
Toilet 5

3.04d [Observe] What type of sanitation facility is this?

$\square$ Flush toilet to piped sewer system

$\square$ Flushed toilet to septic tank

$\square$ Flushed toilet to pit latrine (single or twin)

Flushed toilet to elsewhere (e.g. river, surface, etc.)

Ventilated improved pit latrine (VIP)

$\square$ Pit latrine with slab

$\square$ Pit latrine without slab

$\square$ Composting toilet

$\square$ Bucket

$\square$ Hanging toilet

Community latrines

Other (please specify)

$3.18 \mathrm{~d}$ Is this sanitation facility designated for women and girls only?

$\square$ Yes

$\square$ No

$\square$ Decline to state

$\square$ Don't Know

$3.20 \mathrm{~d}$ Is this sanitation facility designated for staff only?

$\square$ Yes

$\square$ No

Decline to state

$\square$ Don't Know

3.05d [For enumerator] Take a picture of the sanitation facility.

Not Applicable

CC BY-SA 2017, The Water Institute at UNC 
3.11d [Observe] Does the sanitation facility have a superstructure?

$\square$ Yes, with roof

$\square$ Yes, no roof

No

If 3.11d [Observe] Does the sanitation facility have a superstructure? is one of Yes, with roof, Yes, no roof: 3.06d [Observe] Does this sanitation facility have a door which is unlocked (If unsure, ask if a key is available at any time)?

$\square$ Yes

No, key is always available

No, key is not always available

No door

3.07c [Observe] Can the door be closed and locked from the inside?

$\square$ Yes

$\square$ No

3.08c [Observe] Are there barriers on the path, opening, or hole/pit for the sanitation facility that block entry or use.

$\square$ Yes

$\square$ No

3.12c [Observe] Does the sanitation facility have any major holes in the super-structure that allow someone to see through it?

$\square$ Yes

$\square$ No

3.09c [Observe] What type of flooring/slab does this sanitation facility have?

$\square$ Concrete

$\square$ Boards/planks

$\square$ Plastic

Sticks and/or mud

No floor/slab (open pit)

CC BY-SA 2017, The Water Institute at UNC 
$\square$ Other (please specify)

3.10c [Observe] Do you observe any of the following in the sanitation facility? Mark all that apply: $\square$ Unstable slab

$\square$ Pit too big

Pit caving in

Pit full or overflowing

Slab/toilet cracked or broken

$\square$ Facility flooded

$\square$ Bad smell

$\square$ None

3.14c [Observe] Is there a lid covering the hole/slab?

$\square$ Yes

$\square$ No

3.13c [Observe] Are culturally appropriate anal cleansing materials currently available at this sanitation facility?

$\square$ Yes

$\square$ No

3.17c [Observe] Is there functional lighting in this sanitation facility?

$\square$ Yes

$\square$ No

3.15c [Observe] Are feces present on the floor, slab, or walls?

$\square$ Feces present, floor is wet

$\square$ Feces present, floor is dry

$\square$ No feces, floor is wet

$\square$ No feces, floor is dry

3.16c [Observe] Are there flies present?

CC BY-SA 2017, The Water Institute at UNC 
$\square$ Yes, more than 10

Yes, less than 10

No

3.19c [Observe] Which of the following is this sanitation facility equipped with? (Check box next to any that apply.)

a bin with a lid on it within the cubicle

water

soap

private space for washing

None

3.22b [Observe] Does the sanitation facility have any of the following characteristics that would make it difficult for people with limited mobility to use?

$\square$ Path to toilet is difficult to navigate

$\square$ Stairs or steps at the threshold/entrance to the facility

$\square$ No handrails or support on the floor or sidewalls

$\square$ The door is less than $80 \mathrm{~cm}$ wide and/or opens inward

$\square$ The door handles cannot be gripped easily or are too high or low to reach $\square$ There is no seating for persons who are unable to squat, or the existing seat is not easily accessible (too high or too low)

$\square$ Insufficient space inside for a wheelchair user to enter and park by the toilet/latrine

\section{None}

$3.23 \mathrm{~d}$ Is there an additional toilet?

Yes

$\square$ No

If $3.23 \mathrm{~d}$ Is there an additional toilet? is Yes:

3.24 How many additional toilets are there?

$\square$ Don't Know

CC BY-SA 2017, The Water Institute at UNC 
3.25 [Observe] Are hand hygiene stations available in or near all sanitation facilities? ("Near the sanitation facilities" meaning within 5 meters of the sanitation facility exit)

$\square$ Yes, available in or near all sanitatation faciitites

No, available in or near only some sanitation facilitites

$\square$ No, not available in or near any sanitation facilitites

If 3.25 [Observe] Are hand hygiene stations available in or near all sanitation facilities? ("Near the sanitation facilities" meaning within 5 meters of the sanitation facility exit) is one of Yes, available in or near all sanitatation faciitites, No, available in or near only some sanitation facilitites:

3.26. [Observe] Do these hand hygiene stations have soap and water? $\square$ Water and soap available at all hand hygiene stations in or near the sanitation facilities.

$\square$ Water and soap available at some of the hand hygiene stations in or near the sanitation facilities

$\square$ No hand hygiene stations in or near the sanitation facilities have both water and soap.

If 3.25 [Observe] Are hand hygiene stations available in or near all sanitation facilities? ("Near the sanitation facilities" meaning within 5 meters of the sanitation facility exit) is one of Yes, available in or near all sanitatation faciitites, No, available in or near only some sanitation facilitites:

3.26b. [Observe] Do all of these hand hygiene stations have hygienic hand drying materials available?

$\square$ Yes, available at all hand hygiene stations in or near the sanitation facilities.

$\square$ No, available at only some of the hand hygiene stations in or near the sanitation

facilities

$\square$ No hand hygiene stations in or near the sanitation facilities have hygienic hand drying materials

3.30. What measures are taken when the tank or pits are full?

Abandon it

$\square$ Abandon it and construct a new sanitation facility

$\square$ Switch to the second pit/tank/vault onsite (within $5 \mathrm{~m}$ )

Empty the pit/septic tank

$\square$ Nothing

CC BY-SA 2017, The Water Institute at UNC 
$\square$ Other (please specify)

Decline to state

Don't Know

If 0.17 [For Enumerator] Has informed consent been obtained? is Yes:

\section{HYGIENE KNOWLEDGE AND PRACTICES}

Ask the respondent to take you to each of the examination rooms at the health facility and answer the following questions for each health facility.

Examination rooms are points in which medical care is physically provided to patients. If there are more than 4 types of examination rooms, try to visit one of each type. Do not include pharmacies or office spaces.

4.01 What is the main type of care provided in this examination room?

$\square$ General/Internal medicine (e.g. mild illness, physicals)

$\square$ HIV/AIDS treatment

$\square$ Vaccinations

$\square$ Tuberculosis treatment

$\square$ Maternal services

$\square$ Other (please specify)

4.02. [Observe] Is there a hand hygiene station at this point of care?

$\square$ Yes

$\square$ No

If 4.02. [Observe] Is there a hand hygiene station at this point of care? is Yes:

CC BY-SA 2017, The Water Institute at UNC 
4.02a [Observe] Does the hand hygiene station have water and soap or an alcohol based hand rub available?

$\square$ Water

$\square$ Soap

$\square$ Alcohol based hand rub

$\square$ None

If 4.02. [Observe] Is there a hand hygiene station at this point of care? is Yes:

4.03. [Observe] Which of the following are present at this hand hygiene station?

$\square$ Reusable towel

$\square$ Disposable towel

$\square$ Drying machine

$\square$ No method provided

$\square$ Other (please specify)

4.06a [Observe] Are there hand hygiene promotion materials clearly visible and understandable around the examination room?

$\square$ Yes

$\square$ No

4.07. [Observe] How are used sharps and disposable syringes stored in this room?

$\square$ Sharps container

$\square$ Plastic bucket

$\square$ Plastic bag

$\square$ Other (please specify)

$\square$ None stored in this room

4.08. [Observe] Is waste safely segregated into at least three labeled bins in the consultation area?

Hint: (The three bins are: sharps waste, infectious waste, non-infectious general waste. The bins should be clearly labelled (either color coded, written labels or signs), no more than

CC BY-SA 2017, The Water Institute at UNC 
three quarters (75\%) full, and each bin should not contain waste other than that corresponding to their label.)

$\square$ Yes, bins are present and labeled

$\square$ Bins are present but don't meet all requirements

$\square$ No

4.09. [Observe] Are medical gloves available in this room?

$\square$ Yes

$\square$ No

4.10. [Observe] Floor: swept, no obvious dirt or waste

$\square$ Yes

$\square$ No

4.11. [Observe] Counters/tables/chairs: wiped clean no obvious dust or waste

$\square$ Yes

$\square$ No

4.12. [Observe] Needles, sharps outside sharps box

$\square$ Yes

$\square$ No

If 4.07. [Observe] How are used sharps and disposable syringes stored in this room? isn't None stored in this room:

4.13. [Observe] Sharps container overflowing or torn/pierced

$\square$ Yes

$\square$ No

[For Enumerator] Take a picture of the examination room. (include waste bins in the picture.

Not Applicable

4.14. [Observe] Bandages/infectious waste lying uncovered

$\square$ Yes

CC BY-SA 2017, The Water Institute at UNC 
$\square$ No

4.15. Is there an additional examination room?

Hint: If yes, ask if they can take you to it.

$\square$ Yes

$\square$ No

If 4.15. Is there an additional examination room? is Yes:

4.16 Can you show me the next examination room?

$\square$ Yes

$\square$ No

If 4.16 Can you show me the next examination room? is Yes:

\section{Examination Room 2}

4.01a What is the main type of care provided in this examination room?

$\square$ General/Internal medicine (e.g. mild illness, physicals)

$\square$ HIV/AIDS treatment

$\square$ Vaccinations

Tuberculosis treatment

Maternal services

Other (please specify)

4.02a [Observe] Is there a hand hygiene station at this point of care?

$\square$ Yes

$\square$ No

If 4.02a [Observe] Is there a hand hygiene station at this point of care? is Yes:

4.02aa [Observe] Does the hand hygiene station have water and soap or an alcohol based hand rub available?

$\square$ Water

Soap

Alcohol based hand rub

CC BY-SA 2017, The Water Institute at UNC 


\section{None}

If $4.02 \mathrm{a}$ [Observe] Is there a hand hygiene station at this point of care? is Yes:

4.03a. [Observe] Which of the following are present at this hand hygiene station?

\section{Reusable towel}

Disposable towel

Drying machine

No method provided

$\square$ Other (please specify)

4.06aa [Observe] Are there hand hygiene promotion materials clearly visible and understandable around the examination room?
Yes

$\square$ No

4.07a. [Observe] How are used sharps and disposable syringes stored in this room?

\section{Sharps container \\ $\square$ Plastic bucket \\ $\square$ Plastic bag}

$\square$ Other (please specify)

$\square$ None stored in this room

4.08a. [Observe] Is waste safely segregated into at least three labeled bins in the consultation area?

Hint: (The three bins are: sharps waste, infectious waste, non-infectious general waste. The bins should be clearly labelled (either color coded, written labels or signs), no more than three quarters (75\%) full, and each bin should not contain waste other than that corresponding to their label.)

$\square$ Yes, bins are present and labeled

$\square$ Bins are present but don't meet all requirements

$\square$ No

CC BY-SA 2017, The Water Institute at UNC 
4.09a [Observe] Are medical gloves available in this room?

$\square$ Yes

$\square$ No

4.10a [Observe] Floor: swept, no obvious dirt or waste

$\square$ Yes

$\square$ No

4.11a [Observe] Counters/tables/chairs: wiped clean no obvious dust or waste

$\square$ Yes

$\square$ No

4.12a [Observe] Needles, sharps outside sharps box

$\square$ Yes

$\square$ No

If 4.07a. [Observe] How are used sharps and disposable syringes stored in this room? isn't None stored in this room:

4.13a [Observe] Sharps box overflowing or torn/pierced

$\square$ Yes

$\square$ No

4.14a [Observe] Bandages/infectious waste lying uncovered

$\square$ Yes

$\square$ No

$4.15 a$ Is there an additional examination room?

Hint: If yes, ask if they can take you to it.

$\square$ Yes

$\square$ No

4.16a Can you show me the next examination room?

$\square$ Yes

CC BY-SA 2017, The Water Institute at UNC 
$\square$ No

If $4.16 \mathrm{a}$ Can you show me the next examination room? is Yes:

\section{Examination Room 3}

4.01b What is the main type of care provided in this examination room?

General/Internal medicine (e.g. mild illness, physicals)

HIV/AIDS treatment

$\square$ Vaccinations

$\square$ Tuberculosis treatment

$\square$ Maternal services

$\square$ Other (please specify)

4.02b [Observe] Is there a hand hygiene station at this point of care?

$\square$ Yes

$\square$ No

If $4.02 \mathrm{~b}$ [Observe] Is there a hand hygiene station at this point of care? is Yes:

4.02ab [Observe] Does the hand hygiene station have water and soap or an alcohol based hand rub available?

$\square$ Water

Soap

Alcohol based hand rub

$\square$ None

If $4.02 \mathrm{~b}$ [Observe] Is there a hand hygiene station at this point of care? is Yes:

4.03b. [Observe] Which of the following are present at this hand hygiene station?

$\square$ Reusable towel

$\square$ Disposable towel

$\square$ Drying machine

$\square$ No method provided

$\square$ Other (please specify)

CC BY-SA 2017, The Water Institute at UNC 
4.06ab [Observe] Are there hand hygiene promotion materials clearly visible and understandable around the examination room?

Yes

No

4.07b. [Observe] How are used sharps and disposable syringes stored in this room?

\section{Sharps container \\ Plastic bucket \\ Plastic bag \\ Other (please specify)}

$\square$ None stored in this room

4.08b [Observe] Is waste safely segregated into at least three labeled bins in the consultation area?

Hint: (The three bins are: sharps waste, infectious waste, non-infectious general waste.

The bins should be clearly labelled (either color coded, written labels or signs), no more than three quarters (75\%) full, and each bin should not contain waste other than that corresponding to their label.)

$\square$ Yes, bins are present and labeled

Bins are present but don't meet all requirements

No

4.09b [Observe] Are medical gloves available in this room?

Yes

$\square$ No

4.10b [Observe] Floor: swept, no obvious dirt or waste

$\square$ Yes

$\square$ No

4.11b [Observe] Counters/tables/chairs: wiped clean no obvious dust or waste

CC BY-SA 2017, The Water Institute at UNC 


\section{$\square$ Yes}

$\square$ No

4.12b [Observe] Needles, sharps outside sharps box

$\square$ Yes

$\square$ No

If 4.07b. [Observe] How are used sharps and disposable syringes stored in this room? isn't None stored in this room:

4.13b [Observe] Sharps box overflowing or torn/pierced

$\square$ Yes

$\square$ No

4.14b [Observe] Bandages/infectious waste lying uncovered

$\square$ Yes

$\square$ No

4.15b Is there an additional examination room?

Hint: If yes, ask if they can take you to it.

$\square$ Yes

$\square$ No

If $4.15 \mathrm{~b}$ Is there an additional examination room? is Yes:

4.16b Can you show me the next examination room?

$\square$ Yes

$\square$ No

If $4.16 \mathrm{~b}$ Can you show me the next examination room? is Yes:

\section{Examination Room 4}

4.01c What is the main type of care provided in this examination room?

$\square$ General/Internal medicine (e.g. mild illness, physicals)

HIV/AIDS treatment

Vaccinations

$\square$ Tuberculosis treatment

CC BY-SA 2017, The Water Institute at UNC 
$\square$ Maternal services

$\square$ Other (please specify)

4.02c [Observe] Is there a hand hygiene station at this point of care?

$\square$ Yes

$\square$ No

If 4.02c [Observe] Is there a hand hygiene station at this point of care? is Yes:

$4.02 a c$ [Observe] Does the hand hygiene station have water and soap or an alcohol based hand rub available?

$\square$ Water

Soap

Alcohol based hand rub

None

If 4.02c [Observe] Is there a hand hygiene station at this point of care? is Yes:

4.03c [Observe] Which of the following are present at this hand hygiene station?

Reusable towel

Disposable towel

Drying machine

$\square$ No method provided

$\square$ Other (please specify)

4.06ac [Observe] Are there hand hygiene promotion materials clearly visible and understandable around the examination room?

$\square$ Yes

$\square$ No

4.07c. [Observe] How are used sharps and disposable syringes stored in this room?

$\square$ Sharps container

$\square$ Plastic bucket

CC BY-SA 2017, The Water Institute at UNC 


\section{Plastic bag}

Other (please specify)

None stored in this room

4.08c. [Observe] Is waste safely segregated into at least three labeled bins in the consultation area?

Hint: (The three bins are: sharps waste, infectious waste, non-infectious general waste. The bins should be clearly labelled (either color coded, written labels or signs), no more than three quarters (75\%) full, and each bin should not contain waste other than that corresponding to their label.)

$\square$ Yes, bins are present and labeled

$\square$ Bins are present but don't meet all requirements

$\square$ No

4.09c [Observe] Are medical gloves available in this room?

$\square$ Yes

$\square$ No

4.10c [Observe] Floor: swept, no obvious dirt or waste

$\square$ Yes

$\square$ No

4.11c [Observe] Counters/tables/chairs: wiped clean no obvious dust or waste

$\square$ Yes

$\square$ No

4.12c [Observe] Needles, sharps outside sharps box

$\square$ Yes

No

If 4.07b. [Observe] How are used sharps and disposable syringes stored in this room? isn't None stored in this room:

4.13c [Observe] Sharps container overflowing or torn/pierced

CC BY-SA 2017, The Water Institute at UNC 
$\square$ Yes

$\square$ No

4.14c [Observe] Bandages/infectious waste lying uncovered

$\square$ Yes

$\square$ No

$4.15 \mathrm{c}$ Is there an additional examination room?

$\square$ Yes

$\square$ No

If $4.15 \mathrm{c}$ Is there an additional examination room? is Yes:

4.16c How many additional examination rooms are there?

4.17 Are the health facility's floors, surfaces, and sanitation facilities cleaned at least once a day with water and detergent or disinfectant?

$\square$ Yes, cleaned every day with a disinfectant

$\square$ Yes, cleaned every day with water and detergent

$\square$ Yes, cleaned every day, but just with water

$\square$ Cleaned with a disinfectant less than once a day

$\square$ Cleaned with water and detergent, but less than once a day

$\square$ No

$\square$ Decline to state

Don't Know

4.18. Are mattresses, pillows, and or linens cleaned between each patient with detergent?

$\square$ Yes, between every patient

$\square$ Yes, but not between every patient

$\square$ No, never washed

$\square$ No linens, mattresses or pillows are provided by this facility $\square$ Decline to state

Don't Know

CC BY-SA 2017, The Water Institute at UNC 
4.19. Is equipment sterilized between patients?

$\square$ Yes

$\square$ No

$\square$ Decline to state

Don't Know

If 4.19. Is equipment sterilized between patients? is Yes:

4.20. How is equipment sterilized between patients?

$\square$ Autoclave (pressure and wet heat)

$\square$ Dry heat sterilizer/ electric dry heat sterilizer

$\square$ Boiler or steamer (no pressure, electric or not)

$\square$ Normal sterilization technique is currently non-functional

$\square$ Only single use equipment is used

$\square$ No sterilization equipment used

$\square$ Decline to state

Don't Know

4.21. How does this facility treat and/or dispose of 'infectious waste'?

Hint: waste contaminated with blood and other bodily fluids (e.g. from discarded diagnostic samples),cultures and stocks of infectious agents from laboratory work (e.g. waste from autopsies and infected animals from laboratories), or waste from patients in isolation wards, and equipment (e.g. swabs, bandages and disposable medical devices)

$\square$ Autoclaved

$\square$ Incinerated (two chamber, 850-1000C incinerator)

$\square$ Incinerated (brick incinerator)

$\square$ Open burning

$\square$ Open dumping without treatment

$\square$ Chemical disinfection with hypochlorite

$\square$ Not treated, but buried in lined, protected pit

$\square$ Not treated and added to general waste

$\square$ Not treated, but collected for medical waste

disposal $\square$ Other (please specify)

CC BY-SA 2017, The Water Institute at UNC 
$\square$ Decline to state

\section{Don't Know}

4.22. How does this facility treat and/or dispose of sharps waste?

\section{Autoclaved}

$\square$ Incinerated (two chamber, 850-1000C incinerator)

$\square$ Incinerated (brick incinerator)

$\square$ Open burning

$\square$ Open dumping without treatment

$\square$ Chemical disinfection with hypochlorite

$\square$ Not treated, but buried in lined, protected pit

$\square$ Not treated and added to general waste

$\square$ Not treated, but collected for medical waste

disposal $\square$ Other (please specify)

$\square$ Decline to state

Don't Know

4.22b Do medical staff carry alcohol based rub or sanitizer while on duty?

$\square$ Yes

$\square$ No

$\square$ Decline to state

\section{Don't Know}

If 4.21. How does this facility treat and/or dispose of 'infectious waste'? includes all of Incinerated (two chamber,

850-1000C incinerator) or 4.22. How does this facility treat and/or dispose of sharps waste? includes all of Incinerated (two chamber, 850-1000C incinerator) or 4.21. How does this facility treat and/or dispose of 'infectious waste'? includes all of Incinerated (brick incinerator) or 4.22. How does this facility treat and/or dispose of sharps waste? includes all of Incinerated (brick incinerator):

4.23. [Observe] If incinerating, ask to see the incinerator. Is the incinerator functioning and is fuel available on the day of the visit?

CC BY-SA 2017, The Water Institute at UNC 
$\square$ Yes

$\square$ No

4.23b [Observe] Are there used sharps or medical waste lying around on the ground in the yard of the facility?

$\square$ Yes

$\square$ No

4.24. [Observe] Does the health facility have electricity on the day of the visit?

$\square$ Yes

$\square$ No

4.25. How many days was there no power for at least part of the day in the last 7 days (week)?

Don't Know

$\square$ Not Applicable

If 1.05. Does this facility conduct maternity services including deliveries? is Yes and 0.17 [For Enumerator] Has informed consent been obtained? is Yes:

\section{MATERNAL WASH}

Ask respondent to see the maternity ward.

5.03. [Observe] Is there a functional hand hygiene facility within the delivery room? Hint: A functional hand hygiene station may consist of soap and water with a basin/pan for washing hands, or an alcohol-based hand rub dispenser. If alcohol-based hand rub is used, healthcare staff may carry a dispenser around between points of care

$\square$ Yes, with soap and water present at time of visit

$\square$ Yes, with alcohol based hand sanitizer present at time of visit

$\square$ No, hand hygiene facility is present, but only water is available

$\square$ No, no hand hygiene facility is present

CC BY-SA 2017, The Water Institute at UNC 
If 5.03. [Observe] Is there a functional hand hygiene facility within the delivery room? is one of Yes, with soap and water present at time of visit, Yes, with alcohol based hand sanitizer present at time of visit, No, hand hygiene facility is present, but only water is available:

5.04. Are there hygienic hand drying materials available?

\section{$\square$ Yes \\ $\square$ No}

$\square$ Don't Know

5.05. [Observe] Is there a sanitation facility specific to the delivery room or postnatal ward that can be used by the patient without sharing?

$\square$ Yes

$\square$ Yes, but shared

$\square$ No

If 5.05. [Observe] Is there a sanitation facility specific to the delivery room or postnatal ward that can be used by the patient without sharing? is one of Yes, Yes, but shared:

5.05 a [Observe] Where is the sanitation facility designated for the maternity ward located?

Inside delivery room

$\square$ Within $5 \mathrm{~m}$ of delivery room

$\square$ Within $10 \mathrm{~m}$ of delivery room

$\square>10 \mathrm{~m}$ from delivery room

5.06 Is there a designated space with access to water for mothers to clean themselves postdelivery?

$\square$ Yes, in delivery room

$\square$ Yes, outside of delivery room

$\square$ No

$\square$ Decline to state

$\square$ Don't Know

5.07. [Ask and Observe] Are there materials for cleaning the perineum (region from anus to vulva) of the mother?

$\square$ Yes

$\square$ No

CC BY-SA 2017, The Water Institute at UNC 
5.08. Is the delivery bed surface cleaned between every patient?

$\square$ Yes

$\square$ No

$\square$ Decline to state

Don't Know

5.09. Is a clean plastic or sheet available for every birth?

$\square$ Yes, provided by facility

$\square$ Patients bring their own

$\square$ No

$\square$ Decline to state

$\square$ Don't Know

5.10. [Observe] Is a clean blade or scissors available for cord cutting?

$\square$ Yes

$\square$ No

5.11. [Observe] Are clean string or cord clamps available to tie the umbilical cord?

$\square$ Yes

$\square$ No

5.12. [Observe] Are there clean towels to dry and wrap the baby and mother?

$\square$ Yes

$\square$ No

5.13. [Observe] Is there a sufficient amount of water stored in the delivery room? Hint:

(Sufficient amount of stored water is $100 \mathrm{~L}$ per delivery)

$\square$ Yes

$\square$ No

5.14. How is the placenta (anatomical waste) disposed of? $\square$ Placed in separate lined and covered bin in delivery room and then buried or burnt

$\square$ Placed in infectious waste disposal bin and then buried or burnt

CC BY-SA 2017, The Water Institute at UNC 
$\square$ Placed directly into placenta pit

Placed in general waste

$\square$ Patient takes home in a plastic bag or some other container to keep it separated from contact with humans

$\square$ Patient takes home in a way that does not prevent human contact with placenta $\square$ Other (please specify)

$\square$ Decline to state

$\square$ Don't Know

If 0.17 [For Enumerator] Has informed consent been obtained? is Yes:

\section{Administrative/training}

6.01. Does the facility have an infection control policy/procedure or document?

$\square$ Yes

$\square$ No

$\square$ Decline to state

Don't Know

6.02. Is there an annual budget for the facility which includes funding for $\mathrm{WaSH}$ and infection prevention and control infrastructure, services and personnel? If so, is it sufficient to meet the needs of the facility?

$\square$ Yes, a budget exists which is sufficient to meet the needs of the facility

$\square$ Yes, a budget exists but is insufficient to meet the needs of the facility

$\square$ No budget exists

$\square$ Decline to state

$\square$ Don't Know

6.03. Is there a protocol for operating and maintaining the facility, including procurement of IPC or WASH supplies? If yes, is it followed?

$\square$ Yes, a protocol exists and is followed

$\square$ Yes, a protocol exists but is not followed

$\square$ No protocol exists

CC BY-SA 2017, The Water Institute at UNC 
Decline to state

Don't Know

6.04. Does the facility have a dedicated Infection Prevention and Control (IPC) or WaSH focal person?

$\square$ Yes

$\square$ No

Decline to state

Don't Know

6.05. Is there an infection prevention and control, $\mathrm{WaSH}$, or hygiene committee that employees at this health facility belong to? If yes, have they met in the past 6 months?

$\square$ Yes, and they have met within the past 6 months

$\square$ Yes, but they have not met in the past 6 months

$\square$ No

$\square$ Decline to state

$\square$ Don't Know

6.06. Does the facility have a community-composed oversight committee? If yes, have they met in the past 6 months?

$\square$ Yes, and they have met within the past 6 months

$\square$ Yes, but they have not met in the past 6 months

$\square$ No

$\square$ Decline to state

$\square$ Don't Know

6.07 How many times has there been training on infections control and prevention at this facility in the past 12 months?

\section{Don't Know}

$\square$ Not Applicable

If 6.07 How many times has there been training on infections control and prevention at this facility in the past 12 months? is greater than 0 :

6.08.Is water and sanitation included in infection control and prevention training?

CC BY-SA 2017, The Water Institute at UNC 
$\square$ Yes

$\square$ No

$\square$ Decline to state

$\square$ Don't Know

$\square$ Not Applicable

If 6.07 How many times has there been training on infections control and prevention at this facility in the past 12 months? is greater than 0 :

6.09. Who conducts these trainings?

$\square$ Infection control nurse

$\square$ Environmental Health Officer

$\square$ Sub-Divisional or Divisional Health Sisters

$\square$ Doctors

$\square$ Other (please specify)

$\square$ Decline to state

Don't Know

If 6.07 How many times has there been training on infections control and prevention at this facility in the past 12 months? is greater than 0 :

6.10. Who attends these trainings?

$\square$ Doctor

$\square$ Nurse

$\square$ Environmental Health Officer

$\square$ Janitor

$\square$ Maintenance staff

$\square$ Other (please specify)

$\square$ Decline to state

$\square$ Don't Know

6.11. Is WaSH training provided to health care providers at this facility?

CC BY-SA 2017, The Water Institute at UNC 
$\square$ Yes

$\square$ No

$\square$ Decline to state

$\square$ Don't Know

6.12. Is anything done to make the community aware of the importance of infectionprevention within the facility?

$\square$ Yes

$\square$ No

$\square$ Decline to state

$\square$ Don't Know

If 0.17 [For Enumerator] Has informed consent been obtained? is Yes:

\section{Satisfaction/areas for improvement}

7.01 In what general areas, if any, do you feel this health care facility needs improvements or upgrades? (do not read answers aloud)

$\square$ Personnel (non-medical and medical staff)

$\square$ Infrastructure (water supply, hand washing stations, and toilets)

$\square$ Infection control and prevention practices

$\square$ Building (structure, ventilation, power supply)

$\square$ Waste management (solid, infectious, and hazardous)

$\square$ Informational technology/data or record management

$\square$ Medical technology and supplies (e.g.

consumables) $\square$ Other (please specify)

$\square$ None

$\square$ Don't Know

$\square$ Not Applicable

7.04. What do you see as the biggest challenge to making improvements at this facility?

Availability of human resources

$\square$ Technical expertise

CC BY-SA 2017, The Water Institute at UNC 
$\square$ Supplies/procurement

$\square$ Budget

$\square$ None

$\square$ Other (please specify)

\section{Decline to state}

Don't Know

Read aloud: I will now ask some questions about your satisfaction with the general facilities.

7.05. Are you satisfied with your water service at this health facility?

$\square$ Yes

$\square$ No

$\square$ Decline to state

If 7.05. Are you satisfied with your water service at this health facility? is No:

7.06. Why are you not satisfied with your water service? (Do not read answer choices) (check any and all that apply)

$\square$ Not enough quantity (supply)

$\square$ Poor quality

$\square$ Too far away

$\square$ Unreliable (breaks down often)

$\square$ Too expensive

$\square$ Other (please specify)

$\square$ Decline to state

7.07. Are you satisfied with your sanitation facilities at this health facility?

$\square$ Yes

$\square$ No

CC BY-SA 2017, The Water Institute at UNC 
Decline to state

If 7.07. Are you satisfied with your sanitation facilities at this health facility? is No:

7.08. Why are you not satisfied with your sanitation facilities? (Do not read answer choices) (check any and all that apply)

$\square$ Not enough quantity (supply)

$\square$ Poor quality

$\square$ Too far away

$\square$ Unreliable (breaks down often)

$\square$ Too expensive

$\square$ Facility is currently broken

$\square$ Other (please specify)

\section{Decline to state}

7.09. Are you satisfied with your hygiene facilities at this health facility?

$\square$ Yes

$\square$ No

$\square$ Decline to state

If 7.09. Are you satisfied with your hygiene facilities at this health facility? is No:

7.10. Why are you not satisfied with your hygiene facilities? (Do not read answer choices) (check any and all that apply)

$\square$ Not enough quantity (supply)

$\square$ Poor quality

$\square$ Too far away

$\square$ Unreliable (breaks down often)

$\square$ Too expensive

$\square$ Other (please specify)

$\square$ Decline to state

7.11. Are you satisfied with the cleanliness and infection control practices in your facility?

CC BY-SA 2017, The Water Institute at UNC 
$\square$ Yes

$\square$ No

$\square$ Decline to state

If 7.11. Are you satisfied with the cleanliness and infection control practices in your facility? is No:

7.12. Why are you not satisfied with the cleanliness and infection control practices in your facility? (Do not read answer choices) (check any and all that apply)

Staff do not wash hands at critical times

$\square$ Staff do not wash hands with soap and water or use an alcohol-based hand sanitizer

$\square$ Patients do not wash hands at critical times

$\square$ Patients do not wash hands with soap and water

Facility not cleaned well

$\square$ Facility not cleaned on schedule

$\square$ Sharps not disposed of properly

$\square$ Infectious waste not disposed of properly

$\square$ Equipment not sterilized between patients

$\square$ Mattresses, pillows, and/or linens not cleaned between each patient with detergent

$\square$ Other (please specify)

$\square$ Decline to state

Thank the respondent for their time.

CC BY-SA 2017, The Water Institute at UNC 
If 0.17 [For Enumerator] Has informed consent been obtained? is Yes:

8. THE BELOW QUESTIONS ARE FOR THE ENUMERATOR.

8.01. Did the person answering the questions seem irritated or nervous during the interview?

$\square$ Yes

$\square$ No

8.02. Did you think that the respondent was being truthful?

$\square$ Yes

$\square$ No

8.03. How would you rate the quality of this interview?

Good

$\square$ Fair

$\square$ Poor

8.04. How many people were present when you conducted this interview? Hint: Do not count yourself or other enumerators

8.05. Please list activities which the World Vision organization has done in this health facility to date, if any:

8.06. Other comments: 


\section{REFERENCES}

Adams, J., Bartram, J., Chartier, Y., Adams, J., Bartram, J., \& Chartier, Y. (2008). Essential Environmental Health Standards in Health Care, 57. Retrieved from http://www.who.int/water_sanitation_health/hygiene/settings/ehs_hc/en/

Alhassan, R. K., Spieker, N., van Ostenberg, P., Ogink, A., Nketiah-Amponsah, E., \& de Wit, T. F. R. (2013). Association between health worker motivation and healthcare quality efforts in Ghana. Human Resources for Health, 11(1), 1-11. https://doi.org/10.1186/1478-4491-1137

Bain, R., Cronk, R., Wright, J., Yang, H., Slaymaker, T., \& Bartram, J. (2014). Fecal Contamination of Drinking-Water in Low- and Middle-Income Countries: A Systematic Review and Meta-Analysis. PLoS Medicine, 11(5). https://doi.org/10.1371/journal.pmed.1001644

Bain, R. E. S., Wright, J. A., Christenson, E., \& Bartram, J. K. (2014). Rural: Urban inequalities in post 2015 targets and indicators for drinking-water. Science of the Total Environment, 490(2014), 509-513. https://doi.org/10.1016/j.scitotenv.2014.05.007

Bhattacharyya, S., Issac, A., Rajbangshi, P., Srivastava, A., \& Avan, B. I. (2015). "Neither we are satisfied nor they"-users and provider's perspective: A qualitative study of maternity care in secondary level public health facilities, Uttar Pradesh, India. BMC Health Services Research, 15(1), 1-13. https://doi.org/10.1186/s12913-015-1077-8

Cronk, R., \& Bartram, J. (2018). Environmental conditions in health care facilities in low- and middle-income countries: Coverage and inequalities. International Journal of Hygiene and Environmental Health, 221(3), 409-422. https://doi.org/10.1016/j.ijheh.2018.01.004

Echeverry Ibarra, D. F., Cadavid Ramírez, H., Alonso, J. M., Aponte Mayor, G., \& Gálvis Castaño, A. (2008). Experimental results of a cost-effective ozone generator for water treatment in Colombia. Ozone: Science and Engineering, 30(3), 202-209. https://doi.org/10.1080/01919510801942265

Escamilla, V., Knappett, P. S. K., Yunus, M., Streatfield, P. K., \& Emch, M. (2013). Influence of Latrine Proximity and Type on Tubewell Water Quality and Diarrheal Disease in Bangladesh. Annals of the Association of American Geographers, 103(2), 299-308. https://doi.org/10.1080/00045608.2013.756257

Fechter, A. N. (2017). WATER COMMITTEE ACTIVITIES AND CHARACTERISTICS AFFECTING WATER SYSTEM MANAGEMENT IN NORTHERN GHANA.

Fisher, M., Shields, K., Chan, T., Christensen, E., Cronk, R., Leker, H., ... Bartram, J. (2015). Understanding handpump sustainability: Determinants of rural water source functionality in the Greater Afram Plains region of Ghana. Water Resources Research. https://doi.org/10.1002/2014WR016770. 
Graham, J. P. (2014). Pit Latrines and Their Impacts on Groundwater Quality: A Systematic Review Review Pit Latrines and Their Impacts on Groundwater Quality : A Systematic Review, 121(March 2013), 521-530. https://doi.org/10.1289/ehp.1206028

Guo, A., Bowling, J. M., Bartram, J., \& Kayser, G. (2017). Water, sanitation, and hygiene in rural health-care facilities: a cross-sectional study in Ethiopia, Kenya, Mozambique, Rwanda, Uganda, and Zambia. American Journal of Tropical Medicine and Hygiene, 97(4), 1033-1042. https://doi.org/10.4269/ajtmh.17-0208

Huttinger, A., Dreibelbis, R., Kayigamba, F., Ngabo, F., Mfura, L., Merryweather, B., ... Moe, C. (2017). Water, sanitation and hygiene infrastructure and quality in rural healthcare facilities in Rwanda. BMC Health Services Research, 17(1), 517. https://doi.org/10.1186/s12913-017-2460-4

Huttinger, A., Dreibelbis, R., Roha, K., Ngabo, F., Kayigamba, F., Mfura, L., \& Moe, C. (2015). Evaluation of membrane ultrafiltration and residual chlorination as a decentralized water treatment strategy for ten rural healthcare facilities in rwanda. International Journal of Environmental Research and Public Health, 12(10), 13602-13623. https://doi.org/10.3390/ijerph121013602

JMP. (2016). Monitoring WASH in Health Care Facilities: FINAL Core indicators and questions (revised November 25 th, 2016). Retrieved from https://washdata.org/monitoring/healthcare-facilities

JMP. (2017). JMP METHODOLOGY: 2017 UPDATE \& SDG BASELINES. Retrieved from https://washdata.org/sites/default/files/documents/reports/2018-04/JMP-2017-updatemethodology.pdf

Karkee, R., Lee, A. H., \& Pokharel, P. K. (2014). Women' s perception of quality of maternity services : a longitudinal survey in Nepal. BMC Pregnancy \& Childbirth, 14, 1-7.

Kostyla, C., Bain, R., Cronk, R., \& Bartram, J. (2015). Seasonal variation of fecal contamination in drinking water sources in developing countries: A systematic review. Science of the Total Environment, 514, 333-343. https://doi.org/10.1016/j.scitotenv.2015.01.018

Kumpel, E., \& Nelson, K. L. (2013). Comparing microbial water quality in an intermittent and continuous piped water supply. Water Research, 47(14), 5176-5188. https://doi.org/10.1016/j.watres.2013.05.058

Luby, S. P., Gupta, S. K., Sheikh, M. A., Johnston, R. B., Ram, P. K., \& Islam, M. S. (2008). Tubewell water quality and predictors of contamination in three flood-prone areas in Bangladesh. Journal of Applied Microbiology, 105(4), 1002-1008. https://doi.org/10.1111/j.1365-2672.2008.03826.x

Marjadi, B., \& McLaws, M. L. (2010). Hand hygiene in rural Indonesian healthcare workers: Barriers beyond sinks, hand rubs and in-service training. Journal of Hospital Infection, 76(3), 256-260. https://doi.org/10.1016/j.jhin.2010.06.021 
Mathai, E., Allegranzi, B., Kilpatrick, C., \& Pittet, D. (2010). Prevention and control of health care-associated infections through improved hand hygiene. Indian Journal of Medical Microbiology, 28(2), 100-106. https://doi.org/10.4103/0255-0857.62483

Melberg, A., Diallo, A. H., Tylleskär, T., \& Moland, K. M. (2016). "We saw she was in danger, but couldn't do anything": Missed opportunities and health worker disempowerment during birth care in rural Burkina Faso. BMC Pregnancy and Childbirth, 16(1), 1-11. https://doi.org/10.1186/s12884-016-1089-3

Mosley, L. M., Sharp, D. S., \& Singh, S. (2004). Effects of a Tropical Cyclone on the DrinkingWater Quality of a Remote Pacific Island. Disasters, 28(4), 405-417. https://doi.org/10.1111/j.0361-3666.2004.00266.x

Oliver, J. (2015). PREDICTORS OF E. COLI CONTAMINATION AT RURAL WATER POINTS IN KENYA, MALAWI, MOZAMBIQUE, UGANDA, AND ZAMBIA.

Prüss-Ustün, A., Bartram, J., Clasen, T., Colford, J. M., Cumming, O., Curtis, V., ... Cairncross, S. (2014). Burden of disease from inadequate water, sanitation and hygiene in low- and middle-income settings: A retrospective analysis of data from 145 countries. Tropical Medicine and International Health, 19(8), 894-905. https://doi.org/10.1111/tmi.12329

Shields, K., Christenson, E., Ambelu, A., Liang, K., Tezazu, M., \& Bartram, J. (2015). Household stored water and communal source: the impact of geography on the determinants of microbial water quality in rural Ethiopia. Retrieved from https://waterinstitute.unc.edu/files/2014/10/MWA-WQ-Water-and-Health-poster10.23.2015.pdf

Shields, K. F., Bain, R. E. S., Cronk, R., Wright, J. A., \& Bartram, J. (2015). Association of supply type with fecal contamination of source water and household stored drinking water in developing countries: A bivariate meta-analysis. Environmental Health Perspectives, 123(12), 1222-1231. https://doi.org/10.1289/ehp.1409002

Steinmann, P., Bratschi, M. W., Lele, P., Chavan, U., Sundaram, N., Weiss, M. G., ... Hirve, S. (2015). Availability and satisfactoriness of latrines and hand washing stations in health facilities, and role in health seeking behavior of women: evidence from rural Pune district, India. Journal of Water, Sanitation and Hygiene for Development, 5(3), 474. https://doi.org/10.2166/washdev.2015.101

UN. (2017). Sustainable Development Knowledge Platform: Sustainable Development Goal 6. Retrieved from https://sustainabledevelopment.un.org/sdg6

UN Special Rapporteur on the Human Right to Safe Drinking Water and Sanitation. (2012). Report to the General Assembly, Integrating Non-discrimination and Equality into the Post2015 Development Agenda for Water, Sanitation and Hygiene, 8 August 2012. 
WHO. (2017). Guidelines for Drinking-water Quality, Fourth Edition Incorporating The First Addendum. Retrieved from

http://apps.who.int/iris/bitstream/handle/10665/254637/9789241549950-

eng.pdf?sequence $=1$

Wright, J., Gundry, S., \& Conroy, R. (2004). Household drinking water in developing countries: A systematic review of microbiological contamination between source and point-of-use.

Tropical Medicine and International Health, 9(1), 106-117. https://doi.org/10.1046/j.13653156.2003.01160.x 